\title{
Aerosol classification by airborne high spectral resolution lidar observations
}

\author{
S. Groß ${ }^{1}$, M. Esselborn ${ }^{1, *}$, B. Weinzierl ${ }^{1}$, M. Wirth ${ }^{1}$, A. Fix ${ }^{1}$, and A. Petzold ${ }^{1, * *}$ \\ ${ }^{1}$ Institut für Physik der Atmosphäre, Deutsches Zentrum für Luft- und Raumfahrt (DLR), Oberpfaffenhofen, \\ 82234 Weßling, Germany \\ *now at: European Southern Observatory, Karl-Schwarzschild-Str. 2, 85748 Garching, Germany \\ ** now at: Institut für Energie- und Klimaforschung IEK-8: Troposphäre, Forschungszentrum Jülich GmbH, \\ 52425 Jülich, Germany
}

Correspondence to: S. Groß (silke.gross@ dlr.de)

Received: 8 August 2012 - Published in Atmos. Chem. Phys. Discuss.: 2 October 2012

Revised: 6 February 2013 - Accepted: 13 February 2013 - Published: 5 March 2013

\begin{abstract}
During four aircraft field experiments with the DLR research aircraft Falcon in 1998 (LACE), 2006 (SAMUM-1) and 2008 (SAMUM-2 and EUCAARI), airborne High Spectral Resolution Lidar (HSRL) and in situ measurements of aerosol microphysical and optical properties were performed. Altogether, the properties of six different aerosol types and aerosol mixtures - Saharan mineral dust, Saharan dust mixtures, Canadian biomass burning aerosol, African biomass burning mixture, anthropogenic pollution aerosol, and marine aerosol have been studied. On the basis of this extensive HSRL data set, we present an aerosol classification scheme which is also capable to identify mixtures of different aerosol types. We calculated mixing lines that allowed us to determine the contributing aerosol types. The aerosol classification scheme was supported by backward trajectory analysis and validated with in-situ measurements. Our results demonstrate that the developed aerosol mask is capable to identify complex stratifications with different aerosol types throughout the atmosphere.
\end{abstract}

\section{Introduction}

Aerosol particles affect both directly and indirectly the Earth's climate system by scattering solar and terrestrial radiation and by influencing the properties of clouds. In contrast to long-lived greenhouse gases the climate effects of shortlived aerosol particles differ strongly on regional and temporal scales. Currently, the magnitude of the (anthropogenic) aerosol impact on climate causes the largest uncertainty in our knowledge on climate change (Forster et al., 2007). Considerable uncertainties in quantifying the global direct radiative effects of aerosols arise from the variability of the spatial distribution of aerosols as well as from uncertainties associated with aerosol optical and microphysical properties, which vary as a function of aerosol age and type. Reducing these uncertainties requires routine aerosol observations with high vertical and horizontal resolution. Airborne measurements are an appropriate tool for aerosol studies, as they provide highly resolved datasets, but lack in the spatial and temporal coverage of the Earth. Spaceborne lidar systems provide measurements of aerosol layers on a global scale, so they have the potential to advance our knowledge about this important component of the climate system tremendously. However, methods to distinguish different aerosol types and validations of these methods are essential. For example, the Cloud-Aerosol Lidar and Pathfinder Satellite Observations (CALIPSO) mission launched in 2006 (Winker et al., 2007) has completed its sixth year of successful in-orbit operation. Designed as an elastic-backscatter lidar it detects attenuated atmospheric backscatter but lacks the ability of direct extinction measurements. In order to derive aerosol extinction from the lidar backscatter signals the aerosol's extinction-tobackscatter ratio, also commonly referred to as the aerosol lidar ratio $S_{\mathrm{p}}$ has normally to be assumed. There is no standardized value of $S_{\mathrm{p}}$. It rather depends on the particles' microphysical and chemical properties and therefore varies significantly for different aerosol types. Recent studies have 
shown that typical lidar ratios at $532 \mathrm{~nm}$ are $18 \pm 5 \mathrm{sr}$ for marine aerosol (Groß et al., 2011a), $56 \pm 5 \mathrm{sr}$ for desert dust (Tesche et al., 2009a), and $60 \pm 12 \mathrm{sr}$ for arctic haze (Müller et al., 2007). Lidar ratio assumptions for a specific scene not supported by additional information consequently result in doubtful extinction data. Sophisticated aerosol classification algorithms and lidar ratio selection schemes have been developed to help linking the aerosol observations with appropriate lidar ratios (Omar et al., 2009; Müller, D., et al., 2011). However, even if the aerosol type is perfectly identified, the retrieved extinction is subject to the input value of the associated aerosol type's lidar ratio, as is shown e.g. by Wandinger et al. (2010). Consequently, the use of an incorrect lidar ratio would lead to errors in the retrieval of the climate relevant aerosol optical depth (Schuster et al., 2012).

Next-generation spaceborne lidars are designed as high spectral resolution lidars (HSRL) (Ingmann, 2004; Petzold, 2011). Like Raman lidar systems (Ansmann et al., 1990) the HSRL enables direct measurements of aerosol extinction profiles without assumptions of a lidar ratio (Shipley et al., 1983; Shimizu et al., 1983; Hair et al., 2008; Esselborn et al., 2008). Two future satellite missions of the European Space Agency (ESA) will deploy HSRL systems. The ALADIN (Atmospheric LAser Doppler INstrument) instrument (Reitebuch et al., 2009) will be the key instrument of the ESA Atmospheric Dynamics Mission (ADM) and is expected for launch in 2015. It is designed as an incoherent Doppler wind lidar at $355 \mathrm{~nm}$ and is expected to also have potential for extinction profiling (Ansmann et al., 2007). The ATLID (ATmospheric LIDar) instrument will be part of the Earth Clouds, Aerosols and Radiation Explorer (EarthCARE) mission (Ingmann, 2004) aiming for satellite launch in 2015. Measuring at $355 \mathrm{~nm}$, ATLID is expected to provide aerosol and cloud optical properties and, in synergy with other active and passive instruments on board of EarthCARE, collocated samples of the state of the atmosphere along the satellite track.

In this study we show the great potential of combined HSRL and depolarization measurements in a similar way as recently done by Burton et al. (2012). We provide aerosol lidar ratio $S_{\mathrm{p}}$, particle linear depolarization ratio $\delta_{\mathrm{p}}$, and color ratio $\mathrm{CR}$ of various aerosol types measured with HSRL at $532 \mathrm{~nm}$. Our measurements were performed over Europe, the Saharan desert and the Cape Verde Islands and therewith extend the database presented by Burton et al. (2012) especially with respect to fresh Saharan dust collected near the source regions. Furthermore we present a method to calculate $S_{\mathrm{p}}$ and $\delta_{\mathrm{p}}$ for aerosol mixtures, which is crucial to differentiate mixtures from pure aerosol types, and to determine the contributing aerosol types to the mixture. In addition, our findings are supported by trajectory analysis and validated with in-situ measurements. This study demonstrates that different aerosol types can be distinguished using aerosol lidar ratio and particle linear depolarization ratio even if only one HSRL wavelength is available.

\section{Methods}

\subsection{Data basis}

During four field campaigns aerosol properties have been measured by airborne high spectral resolution lidar onboard the DLR Falcon research aircraft and an extensive set of aerosol in-situ instruments. The comprehensive data sets obtained throughout these field experiments contain information on some of the most prominent atmospheric aerosol types: Mineral dust aerosol, sea salt aerosol, biomass burning aerosol, and anthropogenic pollution aerosol. In the following we briefly describe the four field experiments.

- LACE98: The Lindenberg Aerosol Characterization Experiment, Germany, 1998 (Ansmann et al., 1998) took place in July/August 1998 at the Lindenberg Meteorological Observatory of the German Weather Service $\left(52.2^{\circ} \mathrm{N}, 14.1^{\circ} \mathrm{E}\right)$ located $70 \mathrm{~km}$ southeast of Berlin/Germany. LACE98 was carried out as a column closure study (Quinn et al., 1996) with the goal of providing experimental data on the vertical and temporal variability of microphysical and optical aerosol properties measured at a continental European site. Two research aircraft were deployed to probe the aerosol column over the instrumented ground station at Lindenberg: the piston-engine powered Partenavia aircraft carried in-situ instrumentation and probed mainly the boundary layer whereas the turbofan powered DLR Falcon aircraft was equipped with HSRL, radiation and aerosol in-situ instruments and performed flights in the upper troposphere and stacked in-situ profiles across the tropospheric column over the ground site. LACE98 contributes cases of anthropogenically influenced boundary layer aerosol and Canadian forest fire aerosols from a long-range transport event (Petzold et al., 2002) to this study.

- SAMUM-1: The Saharan Mineral Dust Experiment, Morocco, 2006 (Heintzenberg, 2009) took place in May/June 2006 and aimed at the characterization of physical, chemical and radiative properties of African mineral dust. The field experiment involved two instrumented ground stations in southern Morocco: Ouarzazate $\left(30.9^{\circ} \mathrm{N}, 6.9^{\circ} \mathrm{W}\right)$ and Tinfou, which is located about $30 \mathrm{~km}$ southeast of Zagora $\left(30.3^{\circ} \mathrm{N}, 5.8^{\circ} \mathrm{W}\right)$. Similar to LACE98 the Partenavia aircraft and the Falcon aircraft were deployed during SAMUM-1. A total of 17 Falcon research flights were carried out (Weinzierl, 2009; Petzold, 2009; Esselborn, 2009). Ground-based and airborne observations were coordinated with overpasses of MISR (multi-angle imaging spectroradiometer) on NASA's Aqua satellite, and MERIS (medium resolution imaging spectrometer) on ESA's ENVISAT satellite as well (Kahn et al., 2009; Dinter et al., 2009). In this respect SAMUM-1 was among the first studies to combine collocated and 
Table 1. Detailed information about analyzed case studies used for the aerosol classification concerning aerosol type, measurement experiment, date, location, time and altitude range of observation.

\begin{tabular}{|c|c|c|c|c|c|c|}
\hline Aerosol Type & Experiment & Date & Lat & Lon & Time (UTC) & Altitude $[\mathrm{km}]$ \\
\hline \multirow{4}{*}{ Mineral dust } & \multirow{4}{*}{ SAMUM-1 } & 19 May 2006 & 30.9 & -7.6 & 11:09 & $2.0-5.0$ \\
\hline & & 28 May 2006 & 30.1 & -6.5 & $10: 40$ & $1.0-4.0$ \\
\hline & & 3 June 2006 & 30.9 & -6.9 & $07: 40$ & $1.0-4.0$ \\
\hline & & 4 June 2006 & 30.9 & -6.9 & $09: 47$ & $1.5-4.5$ \\
\hline \multirow{5}{*}{ Mixed dust } & \multirow{5}{*}{ SAMUM-2 } & 19 Jan 2008 & 19.0 & 21.5 & $16: 45$ & $0.5-1.0$ \\
\hline & & 25 Jan 2008 & 14.9 & -22.3 & $15: 10$ & $0.8-1.2$ \\
\hline & & 28 Jan 2008 & 17.5 & -22.2 & $10: 30$ & $1.0-1.4$ \\
\hline & & 29 Jan 2008 & 14.9 & -21.5 & $13: 20$ & $0.8-1.2$ \\
\hline & & 4 Feb 2008 & 12.6 & -21.1 & $16: 00$ & $0.8-1.2$ \\
\hline \multirow{5}{*}{$\mathrm{BBA}^{*}$} & \multirow{5}{*}{ SAMUM-2 } & 19 Jan 2008 & 19.0 & 21.5 & $16: 45$ & $2.5-3.5$ \\
\hline & & 23 Jan 2008 & 11.2 & -19.9 & $17: 15$ & $2.0-3.0$ \\
\hline & & 4 Feb 2008 & 12.6 & -21.1 & $16: 00$ & $3.0-4.0$ \\
\hline & & 5 Feb 2008 & 14.9 & -22.5 & $15: 00$ & $3.5-4.0$ \\
\hline & & 5 Feb 2008 & 14.8 & -21.9 & $17: 45$ & $3.5-4.0$ \\
\hline \multirow{5}{*}{ marine } & \multirow{5}{*}{ SAMUM-2 } & 19 Jan 2008 & 36.5 & -9.8 & $11: 30$ & $0.2-0.4$ \\
\hline & & 4 Feb 2008 & 12.6 & -21.1 & $16: 00$ & $0.1-0.3$ \\
\hline & & 5 Feb 2008 & 14.9 & -22.5 & $15: 00$ & $0.1-0.3$ \\
\hline & & 5 Feb 2008 & 14.8 & -21.9 & $17: 45$ & $0.1-0.3$ \\
\hline & & 9 Feb 2008 & 21.9 & -19.7 & $10: 00$ & $0.5-1.0$ \\
\hline \multirow{4}{*}{ pollution } & \multirow{4}{*}{ EUCAARI } & 6 May 2008 & 52.8 & 1.6 & $11: 02$ & $0.5-1.3$ \\
\hline & & 6 May 2008 & 51.4 & 11.4 & $16: 08$ & $1.3-2.3$ \\
\hline & & 8 May 2008 & 51.4 & 5.7 & $14: 45$ & $0.1-1.3$ \\
\hline & & 14 May 2008 & 51.4 & -12.9 & $11: 30$ & $0.5-1.5$ \\
\hline $\mathrm{BBC}^{* *}$ & LACE98 & 9 Aug 1998 & 52.0 & 14.2 & $22: 40$ & $4.5-5.3$ \\
\hline
\end{tabular}

* Biomass burning Africa.

** Biomass burning Canada.

coordinated ground-based, airborne and satellite measurements of aerosols to study mineral dust.

- SAMUM-2: The Saharan Mineral Dust Experiment, Cape Verde Islands, 2008 (Ansmann et al., 2011) took place in January/February 2008 and focused on the observation of aged Saharan dust and mixtures of Saharan dust with biomass burning aerosol from the African tropical regions and marine aerosols. Praia $\left(14.9^{\circ} \mathrm{N}\right.$, $23.5^{\circ} \mathrm{W}$ ) the capital of Santiago/Cape Verde was chosen for the ground-based lidar and in-situ measurements. Altogether, the DLR Falcon performed 17 research flights in the well stratified troposphere (Weinzierl et al., 2011; Petzold et al., 2011). Additionally to the winter campaign in January/February 2008 Raman and depolarization lidar measurements were performed by the Leibnitz-Institut für Troposphärenforschung (Tropos), Leipzig, in May and June 2008 (Tesche et al., 2011). In the following we use SAMUM-2 exclusively for the winter campaign in January/February 2008 (also denoted as SAMUM-2a in Tables 4-7). For the additional campaign in May/June 2008 we use SAMUM-2b.
- EUCAARI-LONGREX: The European integrated project on Aerosol Cloud Climate and Air Quality Interactions, Long-range experiment, 2008 (Kulmala et al., 2009) investigated the physical and chemical properties of aerosols on a European scale, involving 48 partners from 25 countries. In May/June 2008 the DLR Falcon research aircraft performed 15 flight missions (Hamburger et al., 2011, 2012). Ground-based measurement activities were carried out at a number of research sites.

The main measurement areas for this study are shown in Fig. 1. Detailed information to the analyzed case studies can be found in Table 1.

\subsection{The DLR High Spectral Resolution Lidar}

The first airborne HSRL system designed and built by DLR and operated during LACE98, is described in Wandinger et al. (2002). Since then the system was under further development. A detailed technical description of the HSRL system deployed during SAMUM-1 and a presentation of its measurements can be found by Esselborn et al. (2008) and 


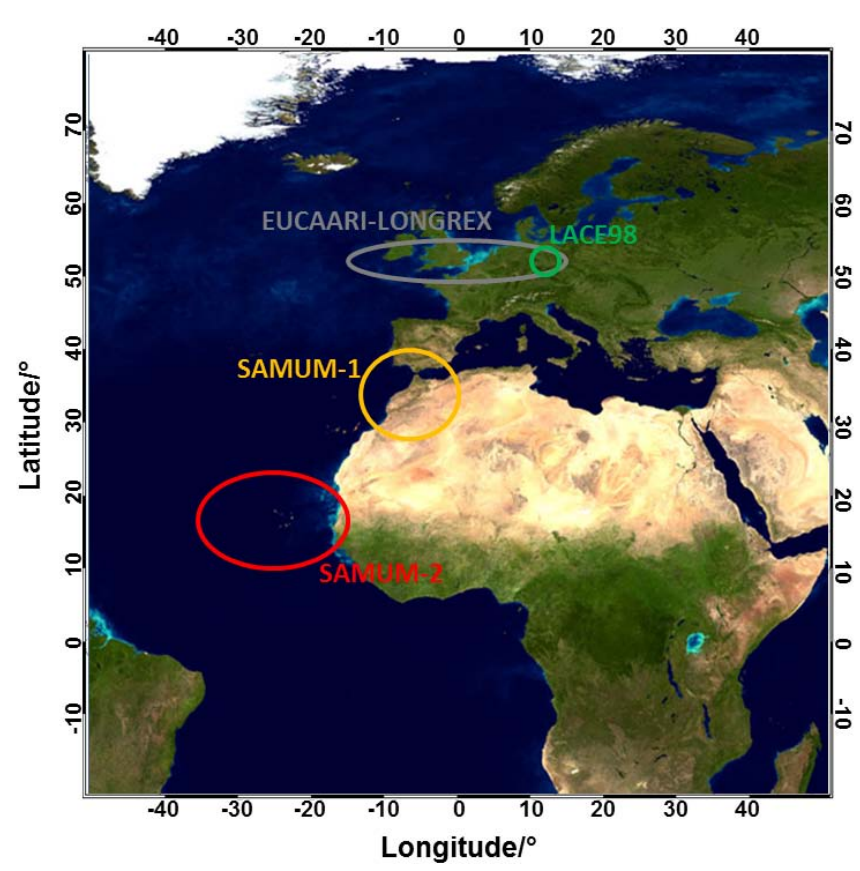

Fig. 1. Main measurement areas of the four considered field experiments on underlying Blue Marble monthly global images for July from NASA's Earth observatory (http://earthobservatory.nasa.gov/ Features/BlueMarble).

Esselborn et al. (2009). The most advanced system was deployed during SAMUM-2 and EUCAARI-LONGREX. The system, also known as WALES (Water vapor Lidar Experiment in Space) has been primarily designed as an airborne high-performance multi-wavelength differential absorption lidar (DIAL) for water vapor measurements at $935 \mathrm{~nm}$ but additionally provides a HSRL-channel at $532 \mathrm{~nm}$ and depolarization channels at $1064 \mathrm{~nm}$ and $532 \mathrm{~nm}$ for aerosol characterization (Wirth et al., 2009). The lidar system utilizes two identical high-power, Q-switched, single-longitudinal-mode Nd:YAG lasers, each of them providing a pulse energy of $400 \mathrm{~mJ}$ at $1064 \mathrm{~nm}$ at a repetition rate of $100 \mathrm{~Hz}$. The fundamental output of each laser is firstly frequency-doubled to $532 \mathrm{~nm}$ and then converted to $935 \mathrm{~nm}$ by an optical parametric oscillator (OPO). The lasers are frequency stabilized to an iodine absorption line. The OPO of both laser systems can be switched on and off, depending on whether water vapor at $935 \mathrm{~nm}$ should be measured or all the power at $532 \mathrm{~nm}$ should be used for the HSRL measurement at $532 \mathrm{~nm}$. During EUCAARI-LONGREX one of the laser systems was used for water vapor measurement and the other was used for HSRL measurements. The backscattered light is collected using a lightweight Cassegrain telescope with an aperture diameter of $0.48 \mathrm{~m}$ and a focal length of $5 \mathrm{~m}$. The field of view of all channels is $1.6 \mathrm{mrad}$. Dichroic beamsplitters are used to spectrally separate the backscatter signals at the three wavelengths. Polarization beamsplitter cubes separate the paralleland cross-polarized components of the backscattered light at $532 \mathrm{~nm}$ and $1064 \mathrm{~nm}$. Typically, the vertical resolution is $15 \mathrm{~m}$ for backscatter and depolarization data with a relative uncertainty of less than $5 \%$ and $10-16 \%$, respectively. The vertical resolution of the extinction and lidar ratio data is $360 \mathrm{~m}-700 \mathrm{~m}$ and the relative uncertainty $10-20 \%$. The signal integration time is typically as short as a few seconds. Both, horizontal and vertical resolution can be varied to suit the measurement situation. The detection limit at $532 \mathrm{~nm}$ is about $0.005 \mathrm{~km}^{-1}$.

\subsection{In-situ instrumentation}

Besides the HSRL system, the Falcon was equipped with a variety of in-situ instruments during all campaigns. The insitu payload consisted of different aerosol sizing instruments, which covered the particle size range from $4 \mathrm{~nm}$ to $100 \mu \mathrm{m}$ in diameter. Instruments sensitive to the sub- $\mu \mathrm{m}$ fraction such as condensation particle counters (CPC) for measuring the particle number concentration and differential mobility analyzers (DMA) were operated inside the aircraft cabin whereas optical sizing instruments covering the size range up to $100 \mu \mathrm{m}$ in diameter were operated outside the fuselage of the Falcon at wing stations. The optical particle spectrometers used during the studies were a Passive Cavity Aerosol Spectrometer Probe (PCASP-100X; $0.12<D_{\mathrm{p}}<3.5 \mu \mathrm{m}$ ) and two Forward Scattering Spectrometer Probes (FSSP-300: $0.3<D_{\mathrm{p}}<30 \mu \mathrm{m}$; FSSP-100: $\left.1.0<D_{\mathrm{p}}<100 \mu \mathrm{m}\right)$. Detailed descriptions of the particle-sizing instrumentation are given by Petzold et al. (2002) and Weinzierl et al. (2009, 2011).

Aerosol absorption was measured inside the cabin at wavelengths 467,530 and $660 \mathrm{~nm}$ by means of a three-wavelength particle soot absorption photometer (PSAP). More detail on the absorption measurements are shown in Petzold et al. $(2009,2011)$. The three-wavelength PSAP can be used to derive an absorption Angström exponent å which characterizes the wavelength-dependence of the aerosol absorption coefficient in terms of a power law $\lambda^{-\mathrm{a}}$. This property has characteristic values for different types of light-absorbing aerosols. It approaches unity for combustion-derived soot particles in anthropogenically polluted air masses and may exceed a value of 3 for mineral dust. During SAMUM-1 and SAMUM-2 typical values of 3.1-5.0 were found for Saharan dust (Petzold et al., 2009; Weinzierl et al., 2011). For African biomass burning mixtures a median value of 1.34 was found (Weinzierl et al., 2011).

\subsection{Measurement strategy}

During all campaigns the DLR HSRL was operated aboard the Falcon research aircraft together with the set of in-situ probing instruments. The HSRL measured aerosol optical quantities at $\lambda=532 \mathrm{~nm}$ namely the aerosol backscatter coefficient, aerosol extinction coefficient, aerosol optical depth, the aerosol lidar ratio and particle linear depolarization ratio. The typical flight distance for the HSRL 
Table 2. Mean value \pm standard deviation of aerosol lidar ratio, particle linear depolarization ratio and color ratio of backscatter for the examined aerosol types, as well as value of maximum frequency, range, and median. The data in brackets give the counts per bin.

\begin{tabular}{|c|c|c|c|c|}
\hline Aerosol Type & mean $\pm s t d v$ & value of maximum frequency & range & median \\
\hline \multicolumn{5}{|c|}{ aerosol lidar ratio [sr] at $532 \mathrm{~nm}$} \\
\hline Saharan dust & $48 \pm 5$ & $47(1538)$ & $33-68$ & 48 \\
\hline mixed Saharan dust & $50 \pm 4$ & $48(1348)$ & $32-71$ & 49 \\
\hline biomass burning mixture (Africa) & $63 \pm 7$ & $60(1601)$ & $36-91$ & 62 \\
\hline biomass burning aerosol (Canada) & $69 \pm 17$ & $61(485)$ & $42-93$ & 65 \\
\hline marine aerosol (North Atlantic) & $18 \pm 5$ & $18(687)$ & $0-33$ & 18 \\
\hline anthropogenic pollution aerosol (Europe) & $56 \pm 6$ & $61(485)$ & $33-72$ & 56 \\
\hline \multicolumn{5}{|c|}{ particle linear depolarization ratio [\%] at $532 \mathrm{~nm}$} \\
\hline Saharan dust & $32 \pm 2$ & $32(806)$ & $25-43$ & 32 \\
\hline mixed Saharan dust & $27 \pm 2$ & $28(1034)$ & $21-31$ & 27 \\
\hline biomass burning mixture (Africa) & $14 \pm 2$ & $15(1245)$ & $8-26$ & 14 \\
\hline biomass burning aerosol (Canada) & $7 \pm 2$ & $6(188)$ & $4-12$ & 7 \\
\hline marine aerosol (North Atlantic) & $3 \pm 1$ & $2(2596)$ & $1-11$ & 2 \\
\hline anthropogenic pollution aerosol (Europe) & $6 \pm 1$ & $6(686)$ & $3-11$ & 6 \\
\hline \multicolumn{5}{|c|}{ color ratio of backscatter } \\
\hline Saharan dust & $1.30 \pm 0.15$ & $1.29(913)$ & $0.7-2.56$ & 1.3 \\
\hline mixed Saharan dust & $1.48 \pm 0.09$ & $1.46(1134)$ & $1.16-1.96$ & 1.48 \\
\hline biomass burning mixture (Africa) & $1.63 \pm 0.13$ & $1.62(1651)$ & $1.04-2.41$ & 1.63 \\
\hline biomass burning aerosol (Canada) & $4.70 \pm 1.30$ & $4.43(108)$ & $2.60-7.21$ & 4.62 \\
\hline marine aerosol (North Atlantic) & $1.64 \pm 0.10$ & $1.6(773)$ & $1.17-2.62$ & 1.64 \\
\hline anthropogenic pollution aerosol (Europe) & $2.43 \pm 0.27$ & $2.3(209)$ & $1.72-3.45$ & 2.41 \\
\hline
\end{tabular}

measurements considered for analysis in this study ranged from about $50 \mathrm{~km}$ to about $150 \mathrm{~km}$. By means of coordinated in-situ soundings, measurements of aerosol number concentration, aerosol number size distribution, and aerosol absorption coefficient have been performed. The sampling strategy during the field experiments generally consisted of two parts: First, remote HSRL sounding was performed at high altitudes to observe and identify interesting aerosol layers. Subsequently, the aerosol layers identified by the HSRL were probed with the in-situ instruments at several different flight altitudes.

As is shown in Fig. 2; vertical in-situ flight patterns consisted of a series of constant altitude flight sequences. Each sequence lasted for at least $5 \mathrm{~min}$. The altitudes of the flight sequences were adjusted from previous lidar measurements. In homogeneous single aerosol layers (e.g. SAMUM-1) minimum two constant-altitude runs were conducted inside the aerosol layer with one close to the lower boundary of the layer or the surface, respectively, and another one close to the top of the aerosol layer. Depending on the vertical extension of the dust layer, a third run was conducted in the center of the aerosol layer, if manageable. In case of multi-layer structures and thin aerosol layers one constant-altitude run within the aerosol layer was performed. During data analysis, each flight sequence was checked for data homogeneity. Particle size distribution data were then averaged over sections of the

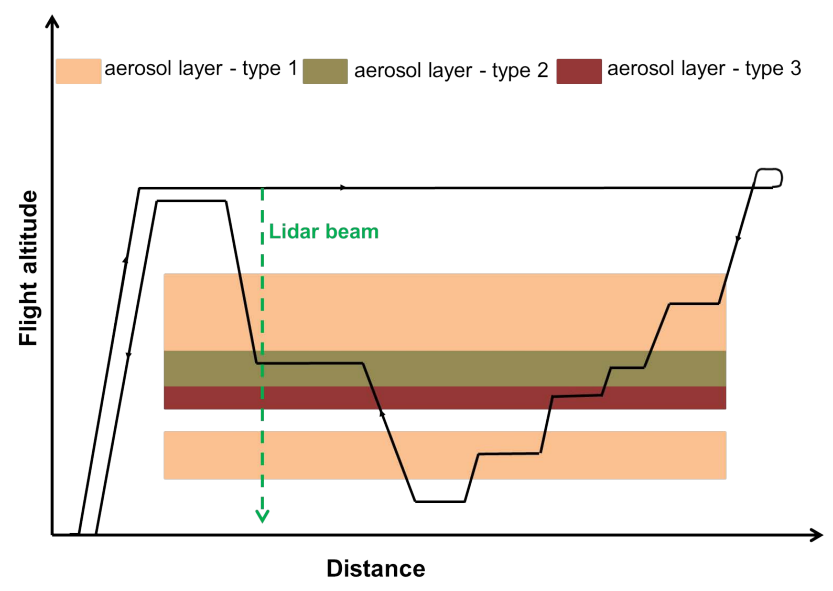

Fig. 2. Flight strategy for coordinated remote sensing and in-situ measurements.

respective flight sequence with homogeneous aerosol conditions.

\subsection{Backward trajectories}

To locate possible aerosol source regions of the analyzed case studies, backward trajectories and satellite images were used. The trajectories were calculated with the Hybrid Single 


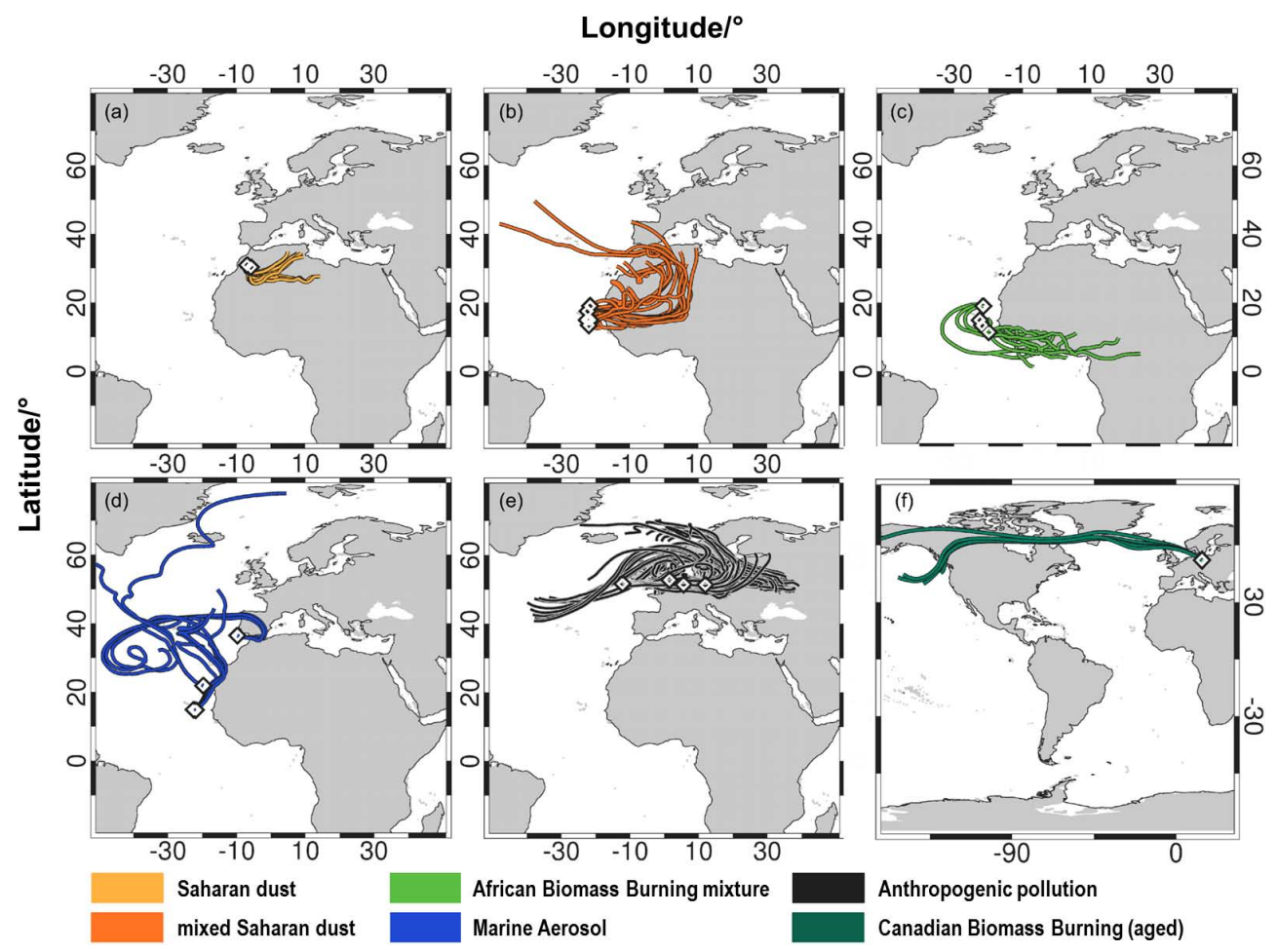

Fig. 3. Backward trajectories for the aerosol layers detected by HSRL measurements (Table 1) and of different origin observed during the LACE98, SAMUM-1, SAMUM-2 and EUCAARI field campaigns. Trajectories date back 5 days for (a), (b), (d) and (e), and 7 days for (c) and (f).

Particle Lagrangian Integrated Trajectory (HYSPLIT) model (Draxler and Rolph, 2012) and the NCEP Global Data Assimilation System (GDAS) data for the interesting sequences and times (Table 2). For LACE98 NCEP Reanalysis data were used. We compared the temporally resolved backward trajectories with information of fire burning times (e.g. MODIS Burnt Area Product), of dust release periods (e.g. Meteosat Second Generation (MSG) dust RGB composite images), and of air pollution, considering the HYSPLIT local mixing layer heights and the trajectories heights, to assess the aerosol source regions of the examined air masses. Uncertainties in this approach, caused by unresolved vertical mixing processes, and by general uncertainties of the trajectory calculations are estimated to be in the range of $15-20 \%$ of the trajectory distance (Stohl et al., 2002). Trajectory calculations with slightly modified initial conditions with respect to the arrival time, location and altitude have been performed to check the reliability of the location of source regions. For detailed examples of backward trajectory analyses see Groß et al. (2011a).

Figure 3 shows back trajectories for the different aerosol types observed during LACE98, SAMUM-1, SAMUM-2 and EURCAARI-LONGREX. The trajectories are colorcoded with respect to distinct aerosol types, representing the aerosol layers identified by the lidar measurements. According to the respective prevailing synoptic situation, the trajec- tories show different flow patterns and source regions for the different campaigns. The source region of the dust loaded air masses during SAMUM-1 and SAMUM-2 are clearly located in the Saharan desert as is obvious from Fig. 3a and b. In contrast, the air masses corresponding to African biomass burning aerosols (Fig. 3c) originate from the central African region and the Gulf of Guinea. During this time of the year most of the forest and grassland fires are located in this area as can be seen from satellite data, e.g. the MODIS fire maps (http://rapidfire.sci.gsfc.nasa.gov/firemaps/), not shown here. Within the marine boundary layer (Fig. 3d) there is no influence of the Saharan desert and African fires. Trajectories for the EUCAARI-LONGREX campaign (Fig. 3e) show a circulating flow pattern over Europe, due to an anti-cyclonic blocking event over Central Europe that led to an increase of pollution concentration within the boundary layer. Air masses observed during LACE98 (Fig. 3f) originated from Canada, where a lot of forest fires were detected at that time.

\section{Results}

\subsection{Vertical layering}

Figure 4 presents the typical stratification for each of the four field experiments. All panels of Fig. 4 show the backscatter ratio $\mathrm{BSR}=\beta / \beta_{\mathrm{m}}$ (with $\beta$ being the total backscatter 

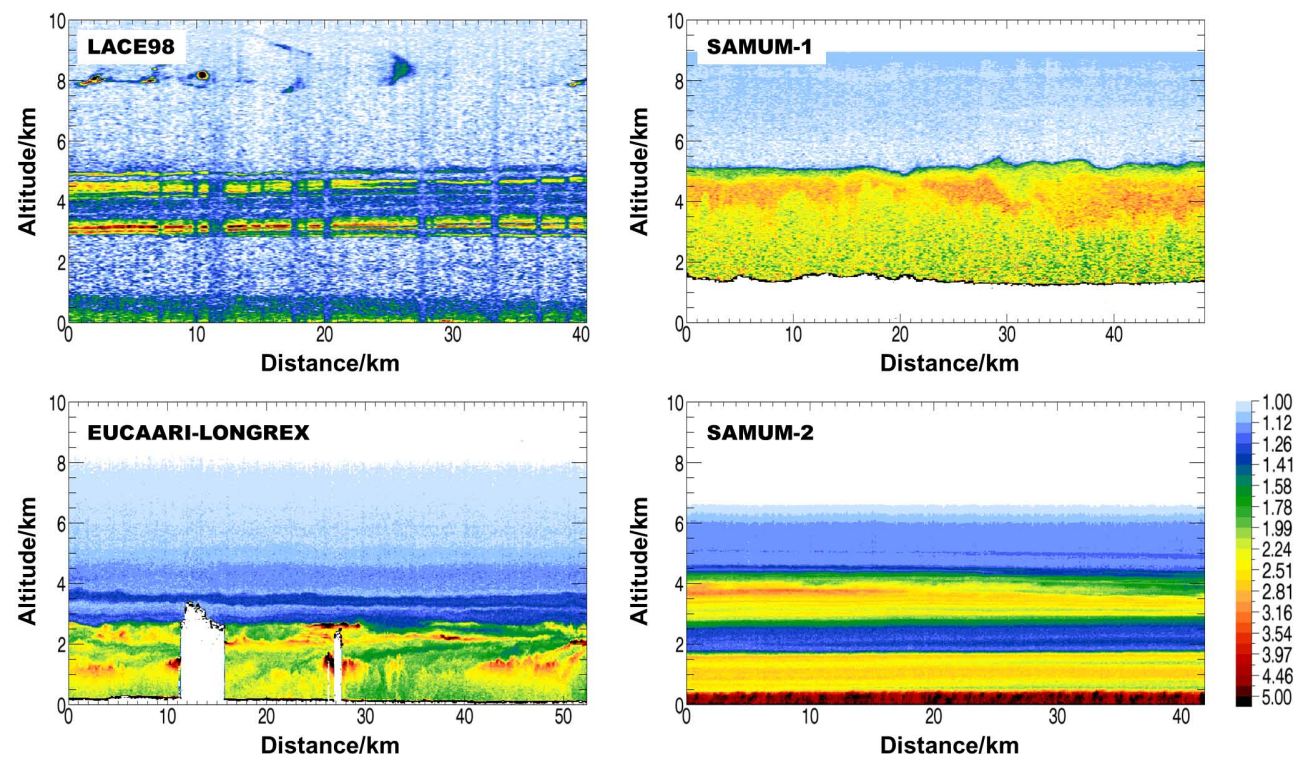

Fig. 4. Selected backscatter ratio cross-sections measured with the HSRL at $532 \mathrm{~nm}$ on 9 August 1998 (LACE98), 6 May 2008 (EUCAARILONGREX), 19 May 2006 (SAMUM-1), and 4 February 2008 (SAMUM-2). Each cross-section is representative for one field experiment and shows the typical vertical structure of the aerosol load during the respective campaign. All cross-sections have the same color-scale.

coefficient and $\beta_{\mathrm{m}}$ being the molecular backscatter coefficient) measured at $532 \mathrm{~nm}$ with the HSRL system. Differences in the aerosol load and vertical structure during the different field experiments are obvious. LACE98 (Fig. 4, upper left panel) was characterized by a shallow boundary layer of less than $1 \mathrm{~km}$ thickness, and an elevated layer between $3-5 \mathrm{~km}$ containing Canadian biomass burning aerosols. The structure of the biomass burning layer was very inhomogeneous. During EUCAARI-LONGREX the anthropogenic pollution aerosol was mainly confined to the boundary layer which extended up to an altitude of about $3 \mathrm{~km}$, and a thin elevated aerosol layer in about $3.5 \mathrm{~km}$ above ground. Convective clouds developed at the boundary layer top (white areas). During SAMUM-1 the Saharan mineral dust aerosol was concentrated in the well-mixed boundary layer and extended from the ground up to about $6 \mathrm{~km}$ above sea level. In contrast to SAMUM-1, the atmosphere during SAMUM2 showed a complex multi-layer structure with a shallow boundary layer of about $0.5 \mathrm{~km}$ extent often topped by a second layer reaching up to $1.5 \mathrm{~km}$ above sea level and an elevated layer in $2-5 \mathrm{~km}$ above sea level.

\subsection{Aerosol type identification}

As we have shown in the previous section, often different aerosol types are present at different altitudes throughout the atmosphere. Therefore column-integrated measurements are not sufficient for a vertically resolved aerosol type classification. Knowledge of the vertical distribution of different aerosol types is important to evaluate radiative heating profiles and to determine the impact of the aerosols on the
Earth's radiative budget which is sensitive to the scattering and absorption properties of the particles and their vertical layering (e.g. Tegen et al., 1996; Sokolik et al., 2001). Either airborne in-situ measurements or a classification scheme based on remote sensing techniques are mandatory. We now present a method for aerosol type classification which uses advanced lidar measurements. To evaluate this classification scheme backward trajectory analysis were used to locate different aerosol types from different source regions, and the lidar optical properties of the specific aerosol types were calculated.

Based on polarization sensitive HSRL measurements, two aerosol specific properties independent from aerosol load, so called intensive properties, the aerosol lidar ratio $S_{\mathrm{p}}$ and the particle linear depolarization ratio $\delta_{\mathrm{p}}$, are derived. Furthermore, the color ratio CR (ratio of aerosol backscatter coefficient at $532 \mathrm{~nm}$ and $1064 \mathrm{~nm}$ ) is calculated. Past analyses of these quantities reveal that characteristic values can be attributed to the different aerosol types (Sasano and Browell, 1989; Tesche et al., 2009b, 2011; Groß et al., 2011a, 2012; Weinzierl et al., 2011; Burton et al., 2012).

Figure 5 shows measurements of the three intensive aerosol quantities, $S_{\mathrm{p}}$ versus $\delta_{\mathrm{p}}$ (Fig. $5 \mathrm{a}$ ), $\delta_{\mathrm{p}}$ versus CR (b), and CR versus $S_{\mathrm{p}}$ (c), as well as the frequency distribution of these intensive quantities (Fig. 5d-f). Different clusters of data pairs can be identified in Fig. 5a-c. It is obvious that $\delta_{\mathrm{p}}$ shows the largest differences for the different aerosol types (Fig. 5a and d). The spread ranges from low $\delta_{\mathrm{p}}$ values for marine aerosols of $1-11 \%$ (mean value: $3 \pm 1 \%$ ) to high $\delta_{\mathrm{p}}$ values of $25-43 \%$ (mean value: $32 \pm 2 \%$ ) for fresh Saharan dust. Values of $\delta_{\mathrm{p}}$ of $21-31 \%$ (mean value: $27 \pm 2 \%$ ) 

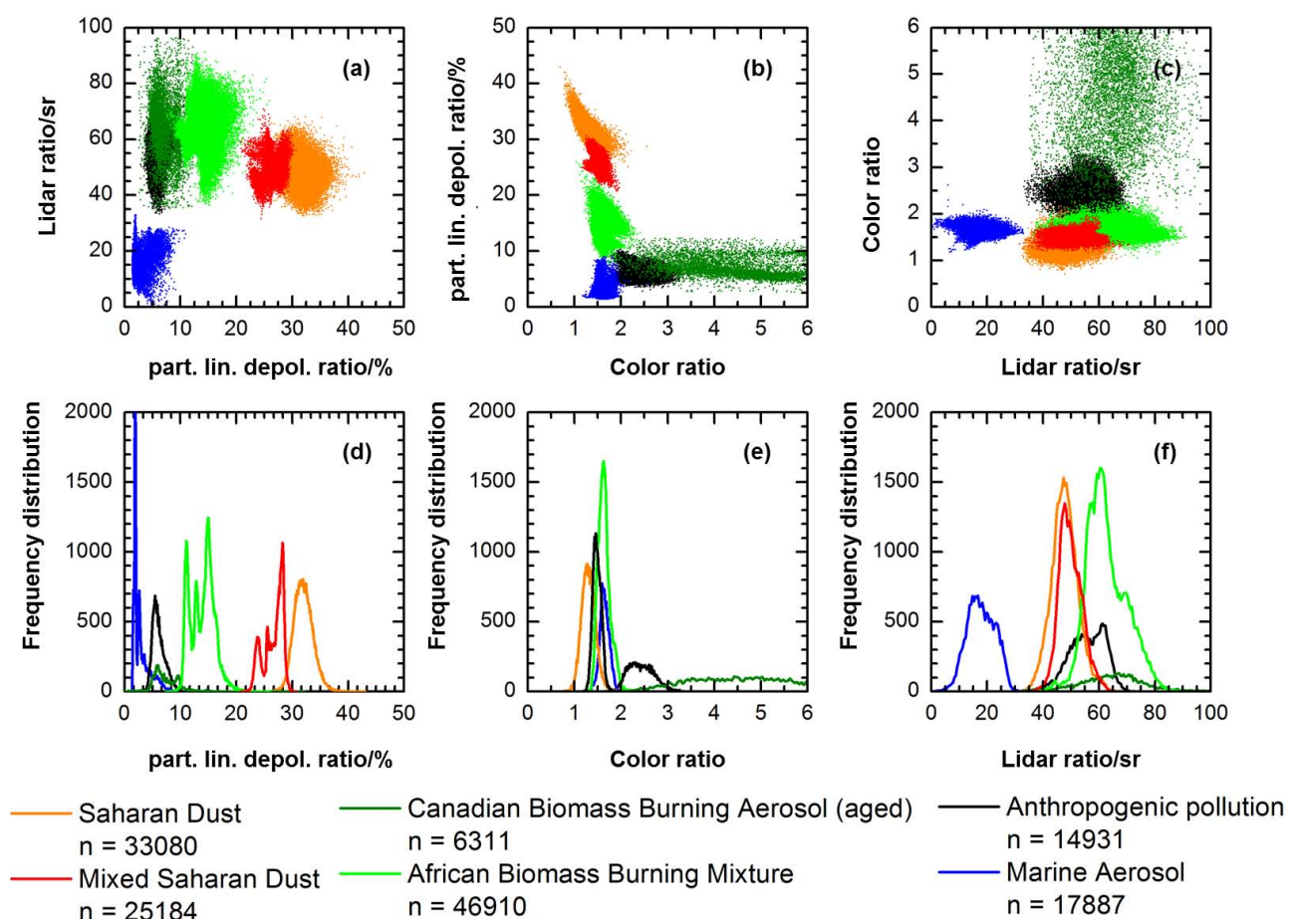

Fig. 5. Characteristic lidar quantities of various atmospheric aerosol types (a)-(c) with frequency distribution (d)-(f), as well as the total number of measurement points (n) for each aerosol type. Each point in (d)-(f) represents a single lidar observation.

were also found in mixed Saharan dust layers while $\delta_{\mathrm{p}}$ of $8-26 \%$ (mean value: $14 \pm 2 \%$ ) were found for African biomass burning mixtures (Weinzierl et al., 2011; Tesche et al., 2009b). Although some (pure) aerosol types are clearly distinguishable by their particle linear depolarization ratio, this parameter fails to differentiate marine aerosols and anthropogenic pollution aerosols or aged (Canadian) biomass burning aerosols. These three aerosol types show quite similar $\delta_{\mathrm{p}}$ values, but differ strongly in color ratio and lidar ratio (Fig. $5 \mathrm{c}$ and f). While $S_{\mathrm{p}}$ for marine aerosols is low with a mean value of $18 \pm 5 \mathrm{sr}(0-33 \mathrm{sr})$, anthropogenic pollution aerosols show a significantly higher mean value of $56 \pm 6 \mathrm{sr}(33-72 \mathrm{sr})$. A similar mean lidar ratio was found for fresh Saharan dust and mixed Saharan dust of $48 \pm 5 \mathrm{sr}$ (33-68 sr) and 50 $\pm 4 \mathrm{sr}(32-71 \mathrm{sr})$, respectively. For African biomass burning mixture a mean value of $63 \pm 7 \mathrm{sr}$ (36$91 \mathrm{sr}$ ) was found. The mean value of Canadian biomass burning aerosols is even higher with $69 \pm 17 \mathrm{sr}$. However, as the aerosol concentration in the Canadian biomass burning layers was very low, the uncertainties in the retrieved intensive aerosol quantities for this aerosol type are large. While $\delta_{\mathrm{p}}$ and $S_{\mathrm{p}}$ show quite different values for the different aerosol types, CR (Fig. 5b and e) is similar for the different types of aerosols, except anthropogenic pollution aerosols and Canadian biomass burning aerosols. Canadian biomass burning aerosols show a wide spread of CR from 2.6 to 7.2 (mean value: $4.70 \pm 1.30$ ), but as mentioned before, the uncertainties are large. For anthropogenic pollution aerosols values range between 1.72 and 3.45 (mean value: $2.43 \pm 0.27$ ). All other examined aerosol types show value of 1.04-2.26 with similar mean values of $1.30 \pm 0.15$ for fresh Saharan dust, $1.48 \pm 0.09$ for mixed Saharan dust, $1.63 \pm 0.13$ for African biomass burning mixtures, and $1.64 \pm 0.10$ for marine aerosols. These examples show that only the combination of different aerosol quantities permits a meaningful discrimination of aerosol types. The mean values of $\delta_{\mathrm{p}}, S_{\mathrm{p}}$ and $\mathrm{CR}$, as well as their range, value of maximum frequency and median are listed in Table 2.

To determine the frequency distribution the sample space was subdivided in bins of $0.1 \%$ in case of the particle linear depolarization ratio, of $0.5 \mathrm{sr}$ in case of the lidar ratio, and of 0.01 in case of the color ratio of backscatter. As can be seen from Fig. 5 the frequency distribution of the color ratio of the backscatter coefficient is quite narrow for most of the aerosol types (Fig. 5e); except for Canadian biomass burning aerosols (see discussion above). Looking at the particle linear depolarization ratio the frequency distribution for the different aerosol types looks different (Fig. 5d). While the frequency distribution shows one main peak for anthropogenic pollution aerosol and Saharan dust, two or more peaks exist for African biomass burning mixtures and mixed Saharan dust, which may be caused by mixing of various amounts of the contributing aerosol types. For marine aerosols a broadening towards higher values is obvious. Although the effects are not as distinctive for the lidar ratio (Fig. 5f) a small second peak at the frequency distribution of the African biomass 


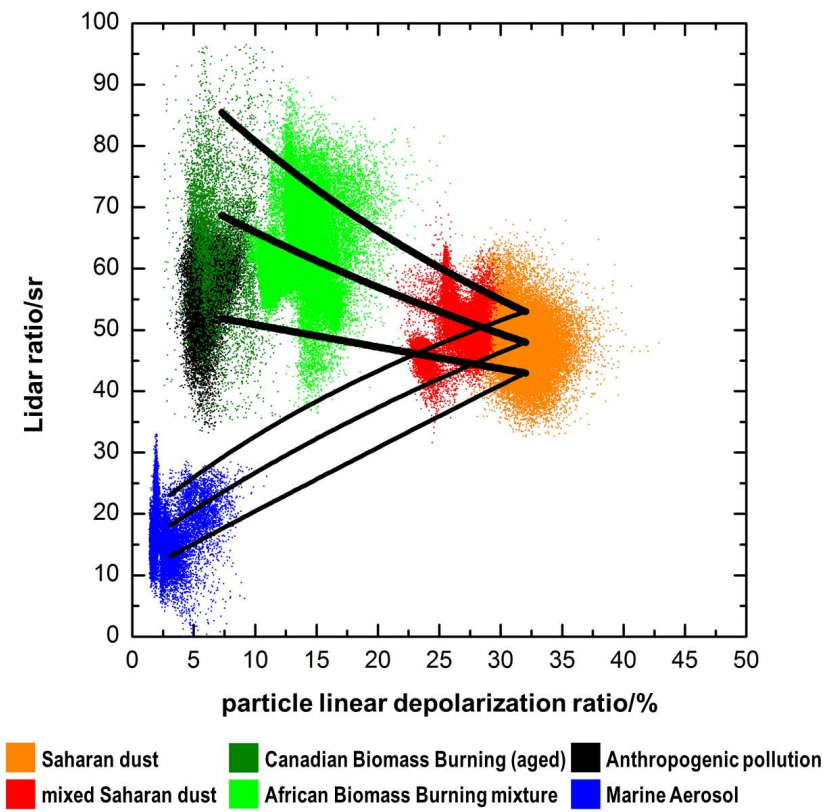

Fig. 6. Aerosol lidar ratio vs. particle linear depolarization ratio for various atmospheric aerosol types and mixing lines for Saharan dust and Canadian Biomass Burning Aerosol (thick lines), and for Saharan dust and Marine aerosol (thin lines). The central line in each case corresponds to the mean values as input for the calculation; the outer lines depict the maximum and minimum range when regarding the uncertainties of the input values.

burning mixtures and the broadening towards higher values for marine aerosols are still visible. As a result, the mean value, the value of maximum frequency and the median of these aerosol types show the largest differences (see Table 2).

\subsection{Aerosol mixtures}

In nature not only "pure" dust, biomass burning, or marine aerosols are observed, but also mixtures of different aerosol types. Now the question is whether these aerosol mixtures can be identified and whether the fraction of the individual aerosol types can be determined on the basis of $\delta_{\mathrm{p}}$ and $S_{\mathrm{p}}$. Figure 6 shows the $S_{\mathrm{p}}-\delta_{\mathrm{p}}$-space. The solid lines in Fig. 6 depict mixing lines for different aerosol types (marine aerosols and Saharan dust - Fig. 6, thin lines; (Canadian) biomass burning aerosols (fine particles) and Saharan dust - Fig. 6, thick lines) based on formulas 5 and 6 in Groß et al. (2011a) using the $S_{\mathrm{p}}$ and $\delta_{\mathrm{p}}$ values of the pure aerosol types to calculate $S_{\mathrm{p}}$ and $\delta_{\mathrm{p}}$ of the mixture. The values of $S_{\mathrm{p}}$ and $\delta_{\mathrm{p}}$ for selected mixing ratios of marine aerosol and Saharan dust mixtures, and Canadian (aged) biomass burning aerosol and Saharan dust mixtures are listed in Table 3.

The second feature visible in Fig. 6 is that the values for the African biomass burning mixture cluster (Fig. 6, green dots) are clearly located within the mixing lines of Saharan dust and (Canadian) biomass burning aerosols. This is in
Table 3. Values of the particle linear depolarization ratio $\left(\delta_{\mathrm{p}}\right)$ and the lidar ratio $\left(S_{\mathrm{p}}\right)$ calculated for selected mixing ratios of marine aerosol and Saharan dust, and of Canadian biomass burning aerosol (CBB) and Saharan dust. The Saharan dust contribution (SD contribution) refers to the fraction of Saharan dust to the total particle extinction coefficient at $532 \mathrm{~nm}$.

\begin{tabular}{|c|c|c|c|c|}
\hline SD contribution & $\delta_{\mathrm{p}}[\%]$ & $S_{\mathrm{p}}[\mathrm{sr}]$ & $\delta_{\mathrm{p}}[\%]$ & $S_{\mathrm{p}}[\mathrm{sr}]$ \\
\hline & \multicolumn{2}{|c|}{ Marine - Saharan Dust } & \multicolumn{2}{|c|}{ CBB - Saharan Dust } \\
\hline $0 \%$ & $3 \pm 1$ & $18 \pm 5$ & $7 \pm 2$ & $59 \pm 17$ \\
\hline $20 \%$ & $5 \pm 2$ & $21 \pm 5$ & $13 \pm 1$ & $63 \pm 13$ \\
\hline $40 \%$ & $8 \pm 3$ & $24 \pm 6$ & $18 \pm 2$ & $59 \pm 10$ \\
\hline $60 \%$ & $12 \pm 2$ & $29 \pm 6$ & $23 \pm 2$ & $55 \pm 8$ \\
\hline $80 \%$ & $19 \pm 2$ & $36 \pm 6$ & $28 \pm 2$ & $51 \pm 6$ \\
\hline $100 \%$ & $32 \pm 2$ & $48 \pm 5$ & $32 \pm 2$ & $48 \pm 5$ \\
\hline
\end{tabular}

agreement with findings of the SAMUM-2 campaign, where Lieke et al. (2011) and Weinzierl et al. (2011) found a contribution of different amount of Saharan dust within these aerosol layers. Besides the African biomass burning mixture cluster, also the mixed Saharan dust cluster (Fig. 6, red dots) is within the mixing lines. During SAMUM-2 a Saharan dust contribution of approximately $10-40 \%$ in the marine aerosol dominated boundary layer was found, and of $85-98 \%$ when the boundary layer was dominated by Saharan dust (Groß et al., 2011b). In the mixed Saharan dust layer the contribution of Saharan dust was about 85-95\% with small contribution of biomass burning aerosols (Weinzierl et al., 2011). The differentiation of mixtures of Saharan dust and marine aerosols, and Saharan dust and biomass burning aerosols is difficult as soon as Saharan dust contributes significantly to that mixture. Furthermore the mixing lines of biomass burning and dust would overlap with mixing lines of e.g. anthropogenic pollution and dust. Thus in those cases further information like trajectory analysis is crucial.

\subsection{Microphysical properties}

Figure 7 summarizes particle number size distributions of identified aerosol types. The distinct properties of identified aerosol types can be directly linked to respective intensive aerosol quantities determined by lidar as will be discussed in the following. In general terms, the lidar ratio $S_{\mathrm{p}}$ is sensitive to the particle size and to the absorption properties: $S_{\mathrm{p}}$ decreases with increasing particle size and increases with increasing light absorption.

In the presented cases all combustion aerosols (anthropogenic pollution, Canadian boreal forest fire, African biomass burning mixture) are characterised by strong light absorption in the visible spectral range and by an absorption Angström exponent of 1-2. Real parts of the complex refractive index of the particles are mostly $>1.5$, and imaginary parts vary from $0.01 i$ to $0.07 i$ for $532 \mathrm{~nm}$ (Wandinger et al., 2002; Petzold et al., 2007; Weinzierl et al., 2011). 

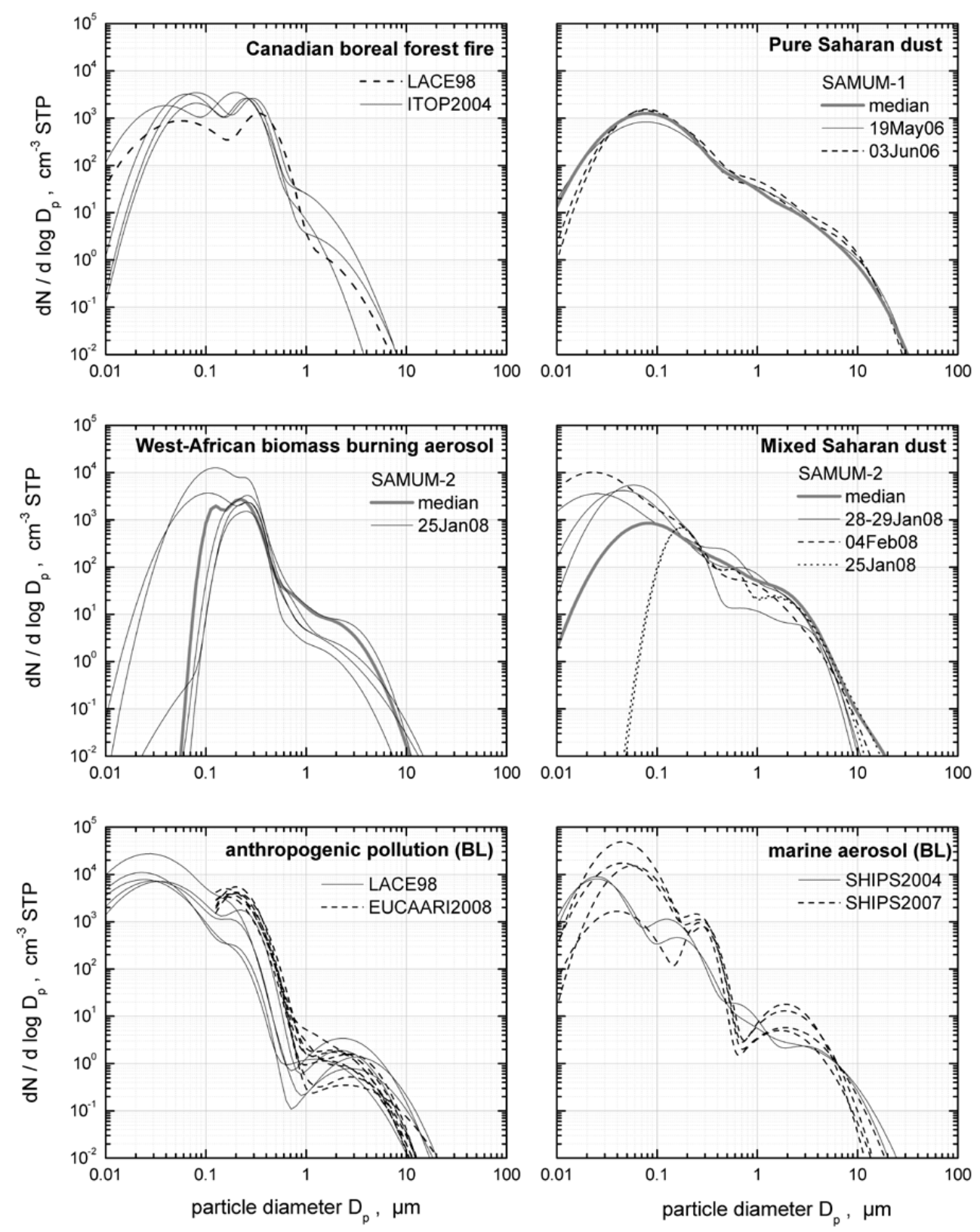

Fig. 7. Representative particle number size distributions for the classified aerosol types: Top left: Canadian boreal forest fire aerosol (LACE98 (Petzold et al., 2002) and ICARTT-ITOP 2004 (Petzold et al., 2007)); mid left: biomass burning aerosol from West African savannah fires (SAMUM-2 (Weinzierl et al., 2011)); bottom left: anthropogenic pollution aerosol over Central Europe (LACE98 (Petzold et al., 2002) and EUCAARI 2008 (Hamburger et al., 2012)); top right: pure Saharan mineral dust over Morocco (SAMUM-1 (Weinzierl et al., 2009)); mid right: Saharan mineral dust mixed with biomass burning aerosol over Cape Verde Islands (SAMUM-2 (Weinzierl et al., 2011)); bottom right: marine boundary layer aerosol over the North Atlantic (SHIPS 2004 (Petzold et al., 2008) and SHIPS 2007).

Respective lidar ratios vary from less than 60 sr to $68 \mathrm{sr}$. Values are highest compared to all observed aerosol types and do not differ significantly among combustion-derived aerosol types. Both Canadian boreal forest fire aerosol and African biomass burning mixture from Savannah fires are characterized by a dominant accumulation mode which peaks between 200 and $300 \mathrm{~nm}$ in diameter. While Canadian forest fire aerosol particles are mainly smaller than $1 \mu \mathrm{m}$ in diameter, the Savannah fire aerosol contains a considerable fraction of super- $\mu \mathrm{m}$ sized particles originating from areas with strong dust emissions further north where the airmasses had passed prior to entering the Savannah fire region. The significant difference in the particle linear depolarization ratio between less than $10 \%$ for Canadian fire aerosols and 


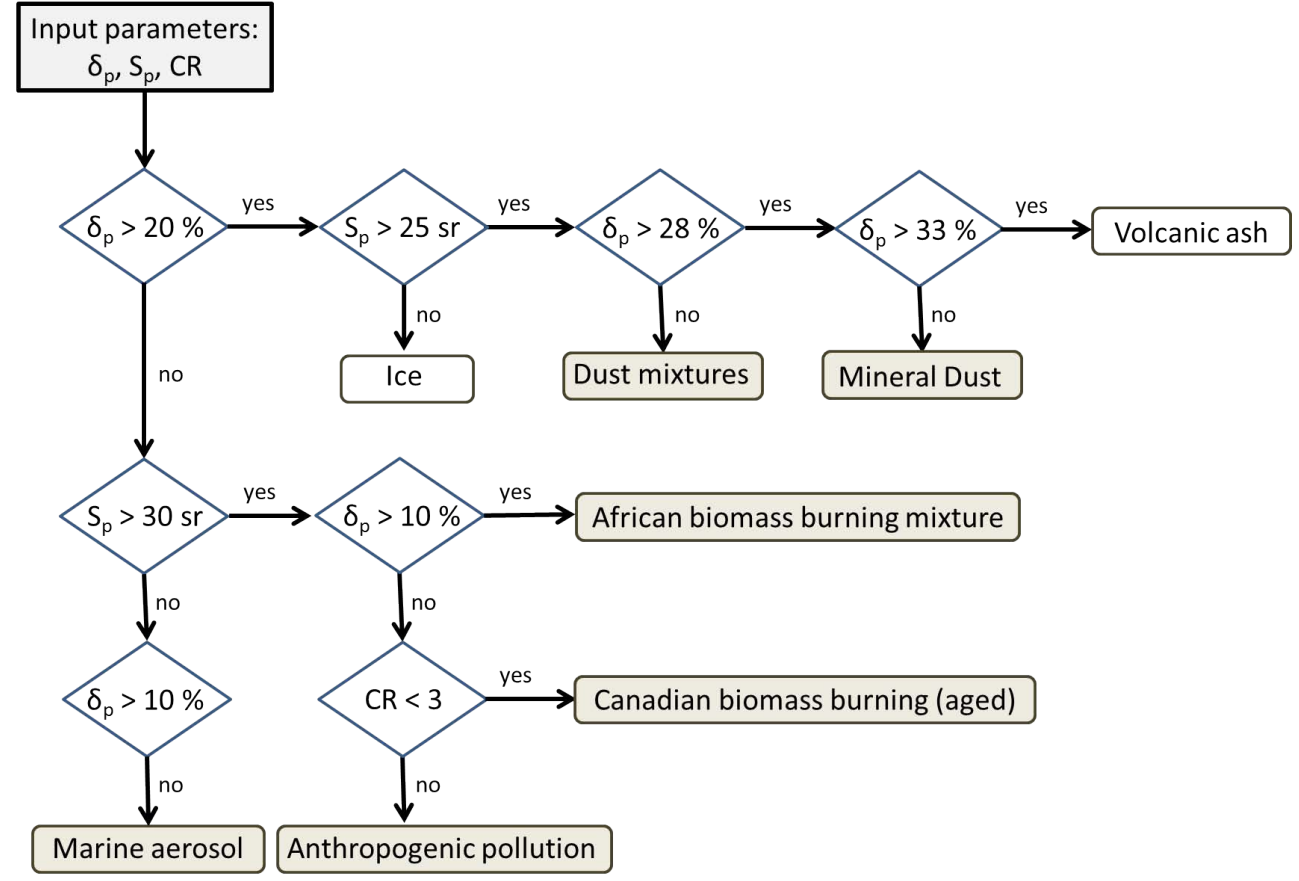

Fig. 8. Flowchart of the aerosol type classification based on three intensive lidar derived optical properties. Grey shaded aerosol types represent aerosol types characterized by DLR HSRL measurements, white shaded aerosol types are defined from literature information.
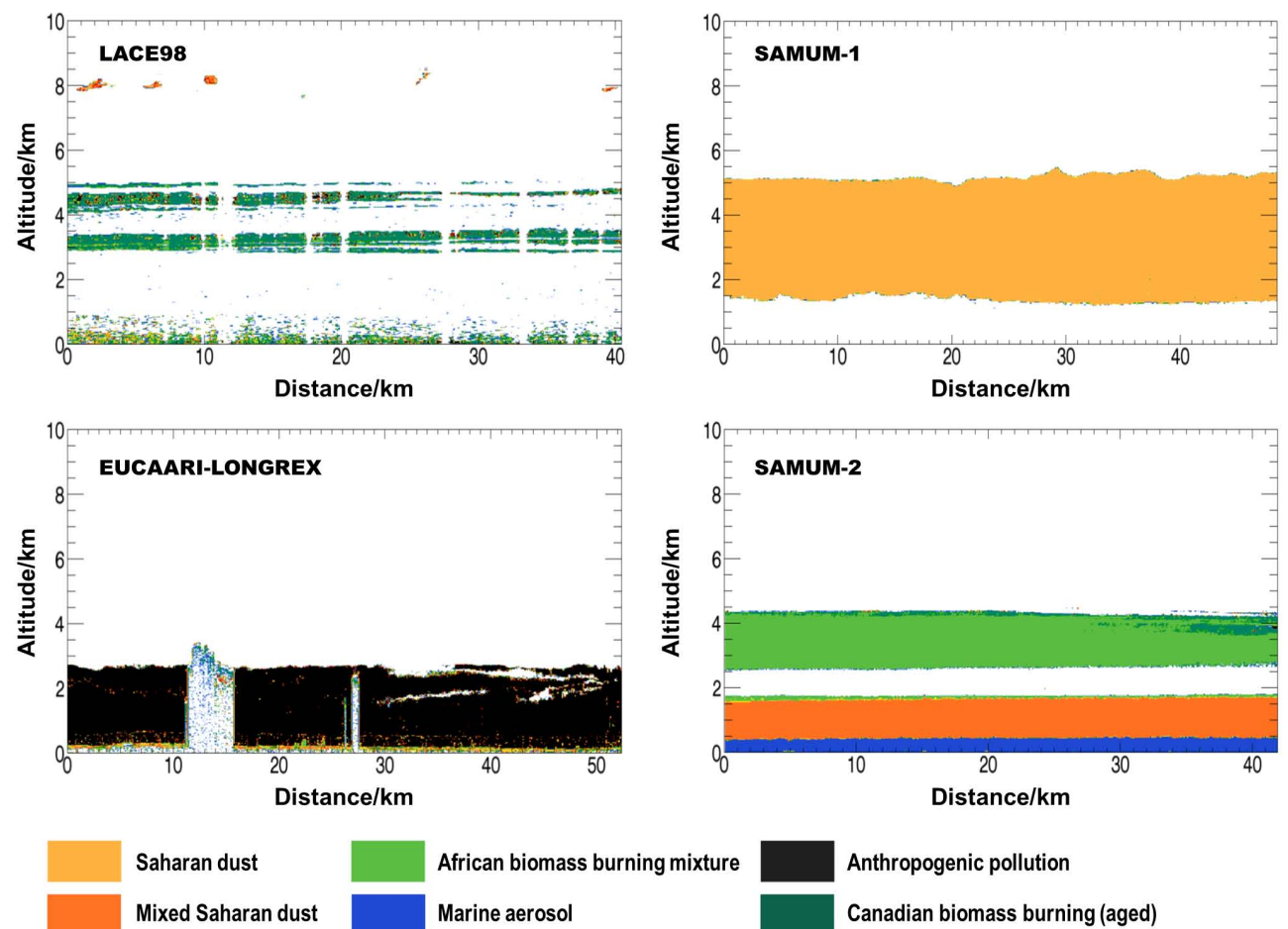

African biomass burning mixture

Marine aerosol

Anthropogenic pollution

Canadian biomass burning (aged)

Fig. 9. Aerosol mask for the measurement examples shown in Fig. 4. The aerosol layers are color-coded corresponding to their aerosol type distinguished by intensive lidar optical properties. As the discrimination of the different aerosol types shown in this figure is based only on our own measurement results (Saharan dust, mixed Saharan dust, African biomass burning mixture, Canadian biomass burning aerosol, anthropogenic pollution, and marine aerosol) a classification for ice is missing; therefore the cirrus clouds in the LACE98 case are misinterpreted. 


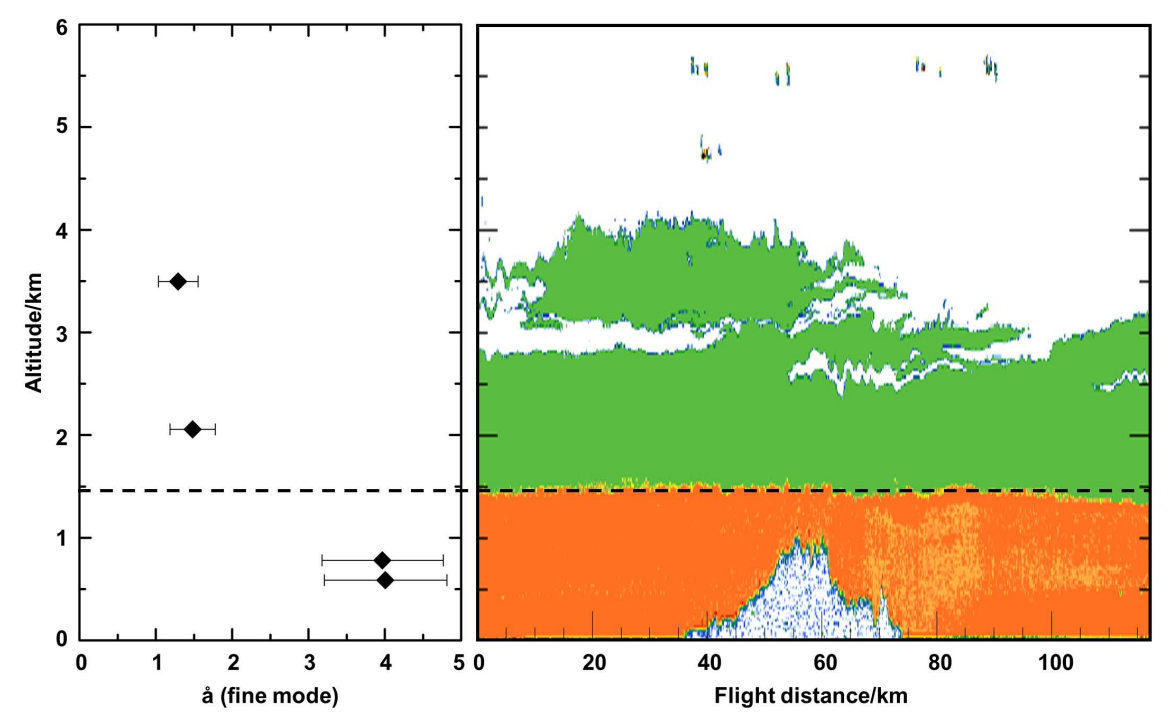

Fig. 10. Measurement example during SAMUM-2 on 25 January 2008. The left panel shows results of the in-situ measurements of the Angstrom exponent of absorption, the right panel shows the lidar signal, color-coded for the observed aerosol type (green for West-African biomass burning mixture, orange for mixed Saharan dust).

Table 4. Summary of the key findings concerning the lidar ratio $\left(S_{\mathrm{p}}\right)$ and the particle linear depolarization ratio $\left(\delta_{\mathrm{p}}\right)$ found in pure desert dust layers.

\begin{tabular}{lllll}
\hline Source & $S_{\mathrm{p}}[\mathrm{sr}]$ & $\delta_{\mathrm{p}}[\%]$ & Comments & Location \\
\hline Sakai et al. (2002) & $46 \pm 5$ & & Fresh Gobi dust & Nagoya, Japan \\
Liu et al. (2002) & $42-55$ & & Asian Dust & Tokyo, Japan \\
Tesche et al. (2009a) & $56 \pm 5$ & & Fresh Saharan dust & SAMUM-1, Morocco \\
Groß et al. (2011a) & $62 \pm 5$ & $31 \pm 1$ & Higher iron content than during SAMUM-1 & SAMUM-2a, Cape Verde Islands \\
Tesche et al. (2011) & $54 \pm 10$ & $31 \pm 1$ & $\delta_{\mathrm{p}}$ calculated from 710 nm & SAMUM-2b, Cape Verde Islands \\
Murayama et al. (2003) & $54 \pm 9$ & $\sim 30$ & Asian Dust & Tokyo, Japan \\
Liu et al. (2008) & & $\sim 32$ & CALIPSO measurements & Transport over the Atlantic Ocean \\
Freudenthaler et al. (2009) & & $32 \pm 2$ & Fresh Saharan dust & SAMUM-1, Morocco \\
Wiegner et al. (2011) & $\sim 59$ & $30-35$ & Long range transport to Central Europe & Munich, Germany \\
Burton et al. (2012) & $49 \pm 9$ & $\sim 33$ & Airborne HSRL measurements & North America \\
Our findings & $48 \pm 5$ & $31 \pm 2$ & Fresh Saharan dust & SAMUM-1, Morocco \\
\hline
\end{tabular}

$14 \pm 2 \%$ for West-African biomass burning mixture can be attributed to the super- $\mu \mathrm{m}$ sized dust particles (see Fig. 6) which were found in the corresponding aerosol layers (Lieke et al., 2011; Weinzierl et al., 2011). The even lower value of $\delta_{\mathrm{p}}$ for anthropogenic pollution aerosol may be associated to the fact that anthropogenic pollution is dominated by an Aitken mode aerosol with its modal diameter well below $100 \mathrm{~nm}$ and an accumulation mode significantly smaller than the accumulation mode for aged biomass burning aerosols of various origins (Petzold et al., 2002; Hamburger et al., 2012).

Besides combustion-derived particles, mineral dust is the other major light-absorbing component of the atmospheric aerosol. However, its ability for light absorption is much weaker than that of carbonaceous combustion particles. Respective refractive index values at $532 \mathrm{~nm}$ are $1.55-1.57$ for the real part and $1 \times 10^{-3}$ to $8 \times 10^{-3}$ for the imaginary part
(Petzold et al., 2009; Weinzierl et al., 2011, 2012). Consequently, pure and mixed mineral dust also show high values of the lidar ratio $S_{\mathrm{p}}$, however at the bottom end of values covered by carbonaceous particles. The significant difference in $\delta_{\mathrm{p}}$ between combustion particles and mineral dust is attributed solely to the dominating fraction of irregularly shaped dust particles in the super- $\mu \mathrm{m}$ size range with its modal diameter at $5-10 \mu \mathrm{m}$.

Marine aerosol also has a significant component of super$\mu \mathrm{m}$ sized sea salt particles. However, since these particles are very likely spherically shaped due to the high relative humidity in the marine boundary layer and the hygroscopic nature of sea salt, the resulting particle linear depolarization ratio is small. Furthermore, sea salt aerosol is mainly nonabsorbing with a vanishing imaginary part of the refractive index so that the resulting lidar ratio is small. Note that for 
Table 5. Summary of the key findings concerning the lidar ratio $\left(S_{\mathrm{p}}\right)$ and the particle linear depolarization ratio $\left(\delta_{\mathrm{p}}\right)$ found for desert dust mixtures.

\begin{tabular}{lllll}
\hline Source & $S_{\mathrm{p}}[\mathrm{sr}]$ & $\delta_{\mathrm{p}}[\%]$ & Comments & Location \\
\hline Ansmann et al. (2003) & $40-80$ & $15-20$ & Unknown mixture & Central Europe \\
Murayama et al. (2004) & $43 \pm 7$ & $\sim 20$ & Unknown mixture & Tokyo Asian dust \\
Chen et al. (2007) & & $14 \pm 6$ & Unknown mixture \\
Groß et al. (2011a) & & $19-28$ & $\begin{array}{l}\text { Mixtures with biomass burning } \\
\text { aerosols and marine aerosols }\end{array}$ & SAMUM-2a, Cape Verde Islands \\
& & & Unknown mixture & Portugal \\
Preißler et al. (2011) & $53 \pm 7$ & $28 \pm 4$ & Central Europe \\
Mattis et al. (2002) & $50-80$ & & Unknown mixture & Athens, Greece \\
Papayannis et al. (2012) & $45-75$ & & Unknown mixture & Beijing, China \\
Xie et al. (2008) & $38 \pm 10$ & $20 \pm 3$ & Unknown mixture & North America \\
Burton et al. (2012) & $30-50$ & $20-35$ & Mixtures with various aerosol types & SAMUM-2a, Cape Verde Islands \\
Our findings & $50 \pm 4$ & $27 \pm 2$ & & \\
\hline
\end{tabular}

this comparison lidar cases of marine boundary layer aerosol were collected during SAMUM-2, while respective particle number size distributions were taken from focused studies in the North Atlantic regions which, however, were conducted without HSRL deployment (Petzold et al., 2008).

In summary, we find that the observed pattern of aerosol optical properties derived from lidar measurements can be linked phenomenological to their intensive microphysical and optical properties.

\section{Discussion}

\subsection{Comparison with prior studies}

\subsubsection{Saharan dust}

The investigation of optical properties of mineral dust is a major topic in atmospheric research. Therefore a number of publications address this subject. At this point only a brief synopsis of the main key findings concerning the examined lidar derived intensive optical properties will be given. Reported are lidar ratios of Saharan dust in the range of about 40-70 sr and a mean particle linear depolarization ratio of about $31 \%$ (Table 4). Considering the lidar ratio, the mean values found for pure Saharan dust during the SAMUM-2 (winter) campaign are slightly higher than those of SAMUM-1 (and other field experiments). However, during the SAMUM-2 (winter) campaign higher iron content was found in the Saharan dust layer (Kandler et al., 2011; Müller, T., et al., 2011) compared to SAMUM-1. As the lidar ratio is dependent on the particles microphysical properties (e.g. Wiegner et al., 2009; Gasteiger et al., 2011; Schuster et al., 2012) the increase in the iron content affects the absorption properties of the aerosols and may explain the slightly higher values found during SAMUM-2. The changes can be attributed to possible differences in the main dust source region of SAMUM-1 and SAMUM-2 (e.g. Groß et al., 2011a) or to aging of the dust particles during transport (see Weinzierl et al., 2011). Our values for the lidar ratio and the particle linear depolarization ratio at $532 \mathrm{~nm}$ for pure Saharan dust are in very good agreement with former findings (Table 4).

\subsubsection{Mixed Saharan dust}

A summary of $\delta_{\mathrm{p}}$ and $S_{\mathrm{p}}$ found from lidar measurements for mixed Saharan dust layers can be found in Table 5. Comparing these results, it has to be kept in mind that the values for the lidar ratio and the particle linear depolarization ratio of dust mixtures strongly depend on the amount of dust in the mixture, and on the kind of mixture, i.e. the contributing aerosol types (see also Table 3).

\subsubsection{Biomass burning and anthropogenic pollution}

Information of $\delta_{\mathrm{p}}$ and $S_{\mathrm{p}}$ found in fresh or aged biomass burning plumes, as well as in pollution aerosol layers are rare. Therefore we summarize the main findings of these aerosol types in one single table (Table 6). Our results for the analyzed aerosol types agree very well with former findings.

\subsubsection{Marine aerosols}

For the lidar derived optical properties $\left(\delta_{\mathrm{p}}\right.$ and $\left.S_{\mathrm{p}}\right)$ of seasalt particles, the relative humidity plays an important role, as shown in former measurements, as $\delta_{\mathrm{p}}$ and $S_{\mathrm{p}}$ depend on the phase (crystalline or liquid) of the particles. The main findings are listed in Table 7. Our results of $\delta_{\mathrm{p}}$ and $S_{\mathrm{p}}$ in marine influenced air masses show good agreement with measurements of liquid sea-salt particles.

\subsubsection{Ice particles and volcanic ash}

We extend the aerosol classification presented in this study to two key atmospheric aerosol types, ice particles and pure volcanic ash. However, as no measurements of ice particles and pure volcanic ash with the DLR HSRL system are available 
Table 6. Summary of the key findings concerning the lidar ratio $\left(S_{\mathrm{p}}\right)$ and the particle linear depolarization ratio $\left(\delta_{\mathrm{p}}\right)$ found in mixed and pure biomass burning aerosol plumes and for anthropogenic pollution.

\begin{tabular}{|c|c|c|c|c|}
\hline Source & $S_{\mathrm{p}}[\mathrm{sr}]$ & $\delta_{\mathrm{p}}[\%]$ & Comments & Location \\
\hline \multicolumn{5}{|c|}{ mixed biomass burning } \\
\hline Tesche et al. (2011) & $67 \pm 12$ & $15 \pm 5$ & Biomass burning/dust & SAMUM-2a, Cape Verde Islands \\
\hline Groß et al. (2011a) & $69 \pm 8$ & $16 \pm 1$ & Biomass burning/dust & SAMUM-2a, Cape Verde Islands \\
\hline Our findings & $63 \pm 7$ & $14 \pm 2$ & & SAMUM-2a, Cape Verde Islands \\
\hline \multicolumn{5}{|c|}{ pure biomass burning } \\
\hline Wandinger et al. (2002) & $40-80$ & & Canadian biomass burning & LACE98, Central Europe \\
\hline Müller et al. (2005) & $26-87$ & $2-3$ & Canadian and Siberian smoke & Central Europe \\
\hline Murayama et al. (2003) & $\sim 65$ & $5-8$ & Siberian smoke & Tokyo, Japan \\
\hline Noh et al. (2008) & $63 \pm 7$ & & Siberian smoke & Korea \\
\hline Ansmann et al. (2009) & $60-70$ & $4-5$ & Aged African biomass burning & Manaus, Brazil \\
\hline Alados-Arboledas et al. (2011) & $60-65$ & & & Granada, Spain \\
\hline Burton et al. (2012) & $30-60$ & $2-5$ & Fresh smoke & North America \\
\hline Burton et al. (2012) & $60-80$ & $3-8$ & Aged Siberian smoke & North America \\
\hline Our findings & $69 \pm 17$ & $7 \pm 2$ & & LACE98, Central Europe \\
\hline \multicolumn{5}{|c|}{ anthropogenic pollution } \\
\hline Wandinger et al. (2002) & $\sim 50$ & & & Central Europe \\
\hline Xie et al. (2008) & $61 \pm 14$ & $\sim 7$ & Moderate pollution & Beijing, China \\
\hline Xie et al. (2008) & $44 \pm 8$ & $\sim 7$ & Heavy pollution & Beijing, China \\
\hline Burton et al. (2012) & $50-70$ & $<10$ & Urban aerosols & North America \\
\hline Our findings & $56 \pm 6$ & $6 \pm 1$ & & LACE98, Central Europe \\
\hline
\end{tabular}

Table 7. Summary of the key findings concerning the lidar ratio $\left(S_{\mathrm{p}}\right)$ and the particle linear depolarization ratio $\left(\delta_{\mathrm{p}}\right)$ found for marine aerosols.

\begin{tabular}{|c|c|c|c|c|}
\hline Source & $S_{\mathrm{p}}[\mathrm{sr}]$ & $\delta_{\mathrm{p}}[\%]$ & Comments & Location \\
\hline Murayama et al. (1999) & & $1-10$ & $\begin{array}{l}\text { Lower values attributed to liquid } \\
\text { sea-salt particles, higher values to } \\
\text { crystalline sea-salt }\end{array}$ & Coastal area of Tokyo Bay, Japan \\
\hline Sakai et al. (2000) & & 10 & Relative humidity $<50 \%$ & Nagoya, Japan \\
\hline Sakai et al. (2000) & & $<5$ & High relative humidity & Nagoya, Japan \\
\hline Sakai et al. (2010) & & 1 & Liquid sea-salt & Laboratory chamber \\
\hline Sakai et al. (2010) & & 8 & Sea-salt crystals & Laboratory chamber \\
\hline Groß et al. $(2011 \mathrm{a}, \mathrm{b})$ & $18 \pm 2$ & $1-3$ & Relative humidity $>50 \%$ & SAMUM-2a, Cape Verde Islands \\
\hline Müller et al. (2007) & $23 \pm 5$ & & Planetary boundary layer & Tropical Indian Ocean \\
\hline Burton et al. (2012) & $15-25$ & $<10$ & & North America \\
\hline Our findings & $18 \pm 5$ & $3 \pm 1$ & & SAMUM-2a, Cape Verde Islands \\
\hline
\end{tabular}

so far; we summarized values from literature in Table 8 for the classification.

\subsection{Aerosol classification}

Different aerosol types have been identified by backtrajectory analysis and independent in-situ data collected during the referred field campaigns. For these different types the intensive optical properties $\delta_{\mathrm{p}}$ and $S_{\mathrm{p}}$ were calculated and showed a classified behavior. Tables 4-7 demonstrated that for a certain type the values of $\delta_{\mathrm{p}}$ and $S_{\mathrm{p}}$ are not dependent on measurement location and measurement time. Therefore $\delta_{\mathrm{p}}$ and $S_{\mathrm{p}}$ can be used to classify the examined aerosol types. Altogether our aerosol data set includes eight main atmospheric aerosol types and mixtures. Based on the pre- sented data set, an aerosol classification scheme has been developed. The aerosol type is identified using the particle linear depolarization ratio, the lidar ratio and the color ratio of backscatter, based on threshold values for $\delta_{\mathrm{p}}, S_{\mathrm{p}}$, and CR. We defined these threshold values according to our findings presented in Sect. 3.2 and to values listed in Tables 4-8. Our final classification scheme is presented in Fig. 8.

From Fig. 5 and Table 2 it is obvious that the particle linear depolarization ratio differs most for specific aerosol types and is therefore the most relevant property for the classification. In contrast the color ratio shows the least differences and has only a minor weight in the classification. It is also obvious that some aerosol types, like e.g. biomass burning and anthropogenic pollution, are harder to separate than others, and measurements of the particle linear depolarization 
Table 8. Summary of the key findings concerning the lidar ratio $\left(S_{\mathrm{p}}\right)$ and the particle linear depolarization ratio $\left(\delta_{\mathrm{p}}\right)$ found for ice particles and pure volcanic ash layers.

\begin{tabular}{|c|c|c|c|c|}
\hline Source & $S_{\mathrm{p}}[\mathrm{sr}]$ & $\delta_{\mathrm{p}}[\%]$ & Comments & Location \\
\hline \multicolumn{5}{|c|}{ Ice Particles } \\
\hline Mischenko and Sassen (1998) & & $30-70$ & Contrails & T-Matrix Calculations \\
\hline Sassen and Hsueh (1998) & & $30-45$ & Cirrus clouds & North America \\
\hline Sassen and Hsueh (1998) & & $60-70$ & Contails & North America \\
\hline Freudenthaler et al. (1996) & & $\sim 50$ & Contrails & Central Europe \\
\hline Sakai et al. (2003) & $<30$ & & Cirrus clouds & Tsukuba, Japan \\
\hline Burton et al. (2012) & $\sim 20$ & & "altostratus nebulosus" & North America \\
\hline \multicolumn{5}{|c|}{ Volcanic ash } \\
\hline Ansmann et al. (2010) & $50-65$ & $\sim 35$ & Eyjafjallajökull & Central Europe \\
\hline Groß et al. (2012) & $50 \pm 5$ & $35-38$ & Eyjafjallajökull & Central Europe \\
\hline Wiegner et al. (2012) & $49 \pm 4$ & $\sim 37$ & Eyjafjallajökull & Central Europe \\
\hline Tsunematsu et al. (2008) & & $>30$ & Mount Asama & Japan \\
\hline
\end{tabular}

ratio and the lidar ratio are not sufficient for a classification. Here additional information of the color ratio may help to separate both types. But still the separation is more unclear than for other types such as mineral dust and marine aerosols. Additional to the ability for a classification of the different aerosol types and mixtures also the uncertainties of the measurements have to be taken into account. As large measurement uncertainties prevent a clear aerosol type separation high quality measurements are mandatory.

Applying the classification scheme of Fig. 8 to the case studies shown in Sect. 3.1, results in Fig. 9. Figure 9 demonstrates that the aerosol mask is capable to identify also the complex stratification during SAMUM-2.

In order to validate the aerosol mask, we use the absorption Angstöm exponent which has been shown to be a good in-situ measure for aerosol types and source regions (e.g. Petzold et al., 2009; Weinzierl et al., 2011). The absorption Angström exponent is only dependent on the aerosol type, and not on its concentration. Figure 10 shows an example for the validation of the aerosol mask with collocated insitu measurements on 25 January 2008 during SAMUM-2: in the left panel of Fig. 7, the absorption Angström exponent is depicted, whereas the right panel shows the aerosol mask derived from the aerosol classification scheme presented in Sect. 4.2 and applied to HSRL results of the research flight on 25 January 2008.

Figure 10 confirms the good agreement of the aerosol classification from lidar derived optical properties with measurements of the absorption Angström exponent. For the latter, values of about 4.0, typical values for dust and dust mixtures, were found in the lower layer, which was classified as mixed Saharan dust layer from lidar measurement (orange color). In the upper layer values of the Angström exponent of absorption of about 1.5, typically for African biomass burning mixtures (Weinzierl et al., 2011), were found. This is in good agreement with the lidar classification of African biomass burning mixtures in this layer (light green color). Trajectory analysis (Sect. 2.5, Fig. 3) supports these findings.

\section{Conclusion}

Aerosol classification as well as the aerosol vertical distribution is needed for remote sensing applications, e.g. CALIPSO, and in radiative transfer simulations for better assessment of the atmospheres vertical heating profiles and the Earth's radiation budget. The aerosol type is characterized by a variety of so called intensive optical and microphysical properties that may partly exhibit large differences. The classification is therefore a delicate process, as it can lead to large errors in the retrieved quantities. The presented work shows the potential of high spectral resolution lidar and depolarization measurements to distinguish between different aerosol types and mixtures by combining three lidar derived intensive aerosol properties, the aerosol lidar ratio, the particle linear depolarization ratio, and the color ratio.

While airborne lidar measurements can be regarded as case studies, satellite measurements provide a global cover of the Earth. Part of the presented approach can in principle also be applied to satellite instruments. Using the measurements of a future polarization-sensitive HSRL system in space (e.g. ATLID onboard EarthCARE), not only the climate relevant optical properties, the aerosol optical depth and the aerosol extinction coefficient, can be derived without further assumptions of the aerosol type. By simultaneous measurements of $S_{\mathrm{p}}$ and $\delta_{\mathrm{p}}$ it would also be possible to directly assign an aerosol type or mixture to a detected aerosol layer. However, the lidar systems of both satellite missions are operated at a different wavelength. Assessments about the adaptability of the presented aerosol type classification to these satellite missions are ongoing and will be the topic of future work. This 
is in particular valuable as the combination of Satellite-based state-of-the-art HSRL and polarization lidar techniques will result in a global distribution of high resolution spatial and vertical information of the structure of clouds and aerosols. Together with collocated passive instruments this advanced methodology is expected to further develop our understanding of the relationship between aerosols and radiation, which is an indispensable pre-requisite for an improved prediction of future climate.

Acknowledgements. This work has been funded partly by the Deutsche Forschungsgemeinschaft (DFG) within the Forschergruppe SAMUM (FOR 539), the European Space Agency (ICAROHS contract no. 22169/NL/CT; XXX contract no. 19429/06/NL/AR), the Helmholtz Association under Grant VH-NG-606 (Helmholtz-Hochschul-Nachwuchsforschergruppe AerCARE), the EC Integrated Project EUCAARI (no. 036833-2), and the DFG HALO-SPP (no. 1294/2). The authors gratefully acknowledge the NOAA Air Resources Laboratory (ARL) for the provision of the HYSPLIT transport and dispersion model and/or READY website used in this publication (http://www.arl.noaa.gov/ready.html). Furthermore we thank Christoph Kiemle for the internal review of this work.

The service charges for this open access publication have been covered by a Research Centre of the Helmholtz Association.

Edited by: E. Gerasopoulos

\section{References}

Alados-Arboledas, L., Müller, D., Guerrero-Rascado, J. L., NavasGuzmn, F., Prez-Ramrez, D., and Olmo, F. J.: Optical and microphysical properties of fresh biomass burning aerosol retrieved by Raman lidar, and star-and sun photometry, Geophys. Res. Lett., 38, L01807, doi:10.1029/2010GL045999, 2011.

Ansmann, A., Riebesell, M., and Weitkamp, C.: Measurement of atmospheric aerosol extinction profiles with a Raman lidar, Opt. Lett., 15, 746-748, doi:10.1364/OL.15.000746, 1990.

Ansmann, A., Wandinger, U., Wiedensohler, A., and Leiterer, U.: Lindenberg aerosol characterization experiment 1998 (LACE 98): Overview, J. Geophys. Res., 107, 8129, doi:10.1029/2000JD000233, 1998.

Ansmann, A., Petzold, A., Kandler, K., Tegen, I., Wendisch, M., Müller, D., Weinzierl, B., Müller, T., and Heintzenberg, J.: Saharan Mineral Dust Experiments SAMUM-1 and SAMUM-2: what have we learned?, Tellus, B63, 403-429, doi:10.1111/j.1600-0889.2011.00555.x, 2001.

Ansmann, A., Bösenberg, J., Chaikovsky, A., Comerón, A., Eckhardt, S., Eixmann, R., Freudenthaler, V., Ginoux, P., Komguem, L., Linné, H., Márquez, M. A. L., Matthias, V., Mattis, I., Mitev, V., Müller, D., Music, S., Nickovic, S., Pelon, J., Sauvage, L., Sobolewsky, P., Srivastava, M. K., Stohl, A., Torres, O., Vaughan, G., Wandinger, U., and Wiegner M.: Long-range transport of Saharan dust to northern Europe: The 1116 October 2001 out- break observed with EARLINET, J. Geophys. Res., 108, 4783, doi:10.1029/2003JD003757, 2003.

Ansmann, A., Ingmann, P., Rille, O. L., Lajas, D., and Wandinger, U.: Particle backscatter and extinction profiling with the spaceborne high-spectral-resolution doppler lidar ALADIN: methodology and simulations, Appl. Opt., 45, 6606-6622, doi:10.1364/AO.46.006606, 2007.

Ansmann, A., Baars, H., Tesche, M., Müller, D., Althausen, D., Engelmann, R., Pauliquevis, T., and Artaxo, P.: Dust and smoke transport from Africa to South America: Lidar profiling over Cape Verde and the amazon rainforest, Geophys. Res. Lett., 36, L11802, doi:10.1029/2009GL037923, 2009.

Ansmann, A., Tesche, M., Groß, S., Freudenthaler, V., Seifert, P., Hiebsch, A., Schmidt, J., Wandinger, U., Mattis, I., Müller, D., and Wiegner, M.: The 16 April 2010 major volcanic ash plume over central Europe: EARLINET lidar and AERONET photometer observations at Leipzig and Munich, Germany, Geophys. Res. Lett., 37, L13810, doi:10.1029/2010GL043809, 2010.

Burton, S. P., Ferrare, R. A., Hostetler, C. A., Hair, J. W., Rogers, R. R., Obland, M. D., Butler, C. F., Cook, A. L., Harper, D. B., and Froyd, K. D.: Aerosol classification using airborne high spectral resolution lidar measurements - methodology and examples, Atmos. Meas. Tech., 5, 73-98, doi:10.5194/amt-5-73-2012, 2012.

Chen, W.-N., Tsai, F.-J., Chou, C. C.-K., Chang, S.-Y., Chen, Y.-W., and Chen, J.-P.: Optical properties of Asian dusts in the free atmosphere measured by Raman lidar at Taipei, Taiwan, Atmos. Environ., 41, 7698-7714, doi:10.1016/j.atmosenv.2007.06.001, 2007.

Dinter, T., von Hoyningen-Huene, W., Burrows, J., Kokhanovsky, A., Bierwirth, E., Wendisch, M., Müller, D., Kahn, R., and Diouri, M.: Retrieval of aerosol optical thickness for desert conditions using meris observations during the SAMUM campaign, Tellus, B61, 229-238, doi:10.1111/j.1600-0889.2008.00391.x, 2009.

Draxler, R. R. and Rolph, G. D.: Hysplit (hybrid single particle lagrangian integrated trajectory) model, NOAA Air Resources Laboratory, Silver Spring, MD, USA, 2012.

Esselborn, M., Wirth, M., Fix, A., Tesche, M., and Ehret, G.: Airborne high spectral resolution lidar for measuring aerosol extinction and backscatter coefficients, Appl. Opt., 47, 346-358, doi:10.1364/AO.47.000346, 2008.

Esselborn, M., Wirth, M., Fix, A., Weinzierl, B., Rasp, K., Tesche, M., and Petzold, A.: patial distribution and optical properties of Saharan dust observed by airborne high spectral resolution lidar during SAMUM 2006, Tellus, B61, 131-143, doi:10.1111/j.1600-0889.2008.00394.x, 2009.

Forster, P., Ramaswamy, V., Artaxo, P., Berntsen, T., Betts, R., Fahey, D. W., Haywood, J., Lean, J., Lowe, D. C., Myhre, G. Nganga, J., Prinn, R., Raga, G., Schulz M., and Van Dorland, R.: Changes in Atmospheric Constituents and in Radiative Forcing. In: Climate Change 2007: The Physical Science Basis, Contribution of Working Group I to the Fourth Assessment Report of the Intergovernmental Panel on Climate Change, edited by: Solomon, S., Qin, D., Manning, M., Chen, Z., Marquis, M., Averyt, K. B., Tignor, M., and Miller, H. L., Cambridge University Press, Cambridge, UK and New York, NY, USA, 2007.

Freudenthaler, V., Homburg, F., and Jäger, H.: Optical parameters of contrails from lidar measurements: Linear depolarization, Geophys. Res. Lett., 23, 3715-3718, doi:10.1029/96GL03646, 1996. 
Freudenthaler, V., Esselborn, M., Wiegner, M., Heese, B., Tesche, M., Ansmann, A., Müller, D., Althausen, D., Wirth, M., Fix, A., Ehret, G., Knippertz, P., Toledano, C., Gasteiger, J., Garhammer, M., and Seefeldner, M.: Depolarization ratio profiling at several wavelengths in pure Saharan dust during SAMUM 2006., Tellus, B61, 165-179, doi:10.1111/j.1600-0889.2008.00396.x, 2009.

Gasteiger, J., Wiegner, M., Groß, S., Freudenthaler, V., Toledano, C., Tesche, M., and Kandler, K.: Modelling lidar-relevant optical properties of complex mineral dust aerosols, Tellus, B 63, 725741, doi:10.1111/j.1600-0889.2011.00559.x, 2011.

Groß, S., Tesche, M., Freudenthaler, V., Toledano, C., Wiegner, M., Ansmann, A., Althausen, D., and Seefeldner, M.: Characterization of saharan dust, marine aerosols and mixtures of biomass burning aerosols and dust by means of multi-wavelength depolarization- and Raman-measurements during SAMUM-2, Tellus, B63, 706-724, doi:10.1111/j.1600-0889.2011.00556.x, 2011a.

Groß, S. Gasteiger, J., Freudenthaler, V., Wiegner, M., Geiß, A., Schladitz, A., Toledano, C., Kandler, K., Tesche, M., Ansmann A., and Wiedensohler A.: Characterization of the planetary boundary layer during SAMUM-2 by means of lidar measurements, Tellus, B63, 695-705, doi:10.1111/j.16000889.2011.00557.x, 2011b.

Groß, S., Freudenthaler, V., Wiegner, M., Gasteiger, J., Geiß, A., and Schnell, F.: Dual-wavelength linear depolarization ratio of volcanic aerosols: Lidar measurements of the Eyjafjallajökull plume over Maisach, Germany, Atmos. Environ., 48, 85-96, doi:10.1016/j.atmosenv.2011.06.017, 2012.

Hamburger, T., McMeeking, G., Minikin, A., Birmili, W., Dall'Osto, M., O'Dowd, C., Flentje, H., Henzing, B., Junninen, H., Kristensson, A., de Leeuw, G., Stohl, A., Burkhart, J. F., Coe, H., Krejci, R., and Petzold, A.: Overview of the synoptic and pollution situation over Europe during the EUCAARILONGREX field campaign, Atmos. Chem. Phys., 11, 10651082, doi:10.5194/acp-11-1065-2011, 2011.

Hamburger, T., McMeeking, G., Minikin, A., Petzold, A., Coe, H., and Krejci, R.: Airborne observations of aerosol microphysical properties and particle ageing processes in the troposphere above Europe, Atmos. Chem. Phys., 12, 11533-11554, doi:10.5194/acp-12-11533-2012, 2012.

Hair, J. W., Hostetler, C. A., Cook, A. L., Harper, D. B., Ferrare, R. A., Mack, T. L., Welch, W., Izquierdo, L. R., and Hovis, F. E.: Airborne High Spectral Resolution Lidar for profiling aerosol optical properties, Appl. Opt., 47, 6734-6752, 2008.

Heintzenberg, J.: The SAMUM-1 experiment over southern morocco: overview and introduction, Tellus, B 61, 2-11, doi:10.1111/j.1600-0889.2008.00403.x, 2009.

Ingmann, P.: EarthCARE - earth clouds, aerosols, and radiation explorer, Tech. Rep., ESA, Sp-1279(1), 2004.

Kahn, R., Petzold, A., Wendisch, M., Bierwirth, E., Dinter, T., Esselborn, M., Fiebig, M., Heese, B., Knippertz, P., Müller, D., Schladitz, A., and von Hoyningen-Huene, W.: Desert dust aerosol air mass mapping in the western Sahara, using particle properties derived from space-based multi-angle imaging, Tellus, B61, 239-251, doi:10.1111/j.1600-0889.2008.00398.x, 2009.

Kandler, K., Schütz, L., Jäckel, S., Lieke, K., Emmel, C., MüllerEbert, D., Ebert, M., Schuvens, D., Schladitz, A., Šegvic, Wiedensohler, A., and Weinbruch, S.: Ground-based off-line aerosol measurements at praia, cape verde, during the Saha- ran mineral dust experiment campaign: Microphysical properties and mineralogical, Tellus, B63, 459-474, doi:10.1111/j.16000889.2011.00546.x, 2011.

Kulmala, M., Asmi, A., Lappalainen, H. K., Carslaw, K. S., Pöschl, U., Baltensperger, U., Hov, Ø., Brenquier, J.-L., Pandis, S. N., Facchini, M. C., Hansson, H.-C., Wiedensohler, A., and O'Dowd, C. D.: Introduction: European Integrated Project on Aerosol Cloud Climate and Air Quality interactions (EUCAARI) - integrating aerosol research from nano to global scales, Atmos. Chem. Phys., 9, 2825-2841, doi:10.5194/acp-9-2825-2009, 2009.

Lieke, K., Kandler, K., Emmel, C., Petzold, A., Weinzierl, B., Scheuvens, D., Ebert, M., Weinbruch, S., and Schütz, L.: Particle chemical properties in the vertical column based on aircraft observations in the vicinity of Cape Verde, Tellus, B63, 497-511, doi:10.1111/j.1600-0889.2011.00553.x, 2011.

Liu, Z., Sugimoto, N., and Murayama, T.: Extinction-to-backscatter ratio of Asian dust observed with high-spectral resolution lidar and Raman lidar, Appl. Opt., 41, 2760-2767, 2002.

Liu, Z., Omar, A., Vaughan, M., Hair, J., Kittaka, C., Hu, Y., Powell, K., Trepte, C., Winker, D., Hostetler, C., Ferrare, R., and Pierce, R.: Calipso lidar observations of the optical properties of Saharan dust: A case study of long-range transport, J. Geophys. Res., 113, D07207, doi:10.1029/2007JD008878, 2008.

Mattis, I., Ansmann, A., Müller, D., Wandinger, U., and Althausen, D.: Dual-wavelength raman lidar observations of the extinctionto-backscatter ratio of Saharan dust, Geophys. Res. Lett., 29, 1306, doi:10.1029/2002GL014721, 2002.

Mishchenko, M. I. and Sassen, K.: Depolarization of lidar returns by small ice crystals: An application to contrails, Geophys. Res. Lett., 25, 309-312, doi:10.1029/97GL03764, 1998.

Müller, D., Mattis, I., Wandinger, U., Ansmann, A., and Althausen, D.: Raman lidar observations of aged Siberian and Canadian forest fire smoke in the free troposphere over Germany in 2003: Microphysical particle characterization, J. Geophys. Res., 110, D17201, doi:10.1029/2004JD005756, 2005.

Müller, D., Ansmann, A., Mattis, I., Tesche, M., Wandinger, U., Althausen, D., and Pisani, G.: Aerosol-type-dependent lidar ratios observed with Raman lidar, J. Geophys. Res., 112, D16202, doi:10.1029/2006JD008292, 2007.

Müller, D., Kolgotin, A., Mattis, I., Petzold, A., and Stohl, A.: Vertical profiles of microphysical particle properties derived from inversion with two-dimensional regularization of multiwavelength Raman lidar data: experiment, Appl. Opt., 50, 2069-2079, 2011.

Müller, T., Schladitz, A., Kandler, K., and Wiedensohler, A.: Spectral particle absorption coefficients, single scattering albedos, and imaginary parts of refractive indices from ground based in-situ measurements at Cape Verde island during SAMUM-2, Tellus, B63, 573-588, doi:10.1111/j.1600-0889.2011.00572.x, 2011.

Murayama, T., Okamoto, H., Kaneyasu, N., Kamataki, H., and Miura, K.: Application of lidar depolarization measurement in the atmospheric boundary layer: Effects of dust and sea-salt particles, J. Geophys. Res., 104, 31781-31792, doi:10.1029/1999JD900503, 1999.

Murayama, T., Masonis, S. J., Redemann, J., Anderson, T. L., Schmid, B., Livingston, J. M., Russell, P. B., Huebert, B., Howell, S. G., McNaughton, C. S., Clarke, A., Abo, M., Shimizu, A., Sugimoto, N., Yabuki, M., Kuze, H., Fukagawa, S., Maxwell-Meier, K., Weber, R. J., Orsini, D. A., Blomquist, 
B., Bandy, A., and Thornton, D.: An intercomparison of lidarderived aerosol optical properties with airborne measurements near Tokyo during ACE-Asia, J. Geophys. Res., 108, 8651, doi:10.1029/2002JD003259, 2003.

Murayama, T., Müller, D., Wada, K., Shimizu, A., Sekiguchi, M., and Tsukamoto, T.: Characterization of Asian dust and Siberian smoke with multiwavelength raman lidar over Tokyo, Japan in spring 2003, Geophys. Res. Lett., 31, L23103, doi:10.1029/2004GL021105, 2004.

Noh, Y. M., Kima, Y. J., and Müller, D.: Seasonal characteristics of lidar ratios measured with a Raman lidar at Gwangju, Korea in spring and autumn, Atmos. Environ., 42, 2208-2224, doi:10.1016/j.atmosenv.2007.11.045, 2008.

Omar, A., Winker, D. M., Kittaka, C., Vaughan, C. R., Liu, Z., M. A., Hu, Y., Trepte, Rogers, R. R., Ferrare, R. A., Lee, K.-P., Kuehn, R. E., and Hostetler, C. A.: The calipso automated aerosol classification and lidar ratio selection algorithm, J. Atmos. Ocean. Tech., 26, 1994-2014, doi:10.1175/2009jtecha1231.1, 2009.

Papayannis, A., Mamouri, R. E., Amiridis, V., Remoundaki, E., Tsaknakis, G., Kokkalis, P., Veselovskii, I., Kolgotin, A., Nenes, A., and Fountoukis, C.: Optical-microphysical properties of Saharan dust aerosols and composition relationship using a multi-wavelength Raman lidar, in situ sensors and modelling: a case study analysis, Atmos. Chem. Phys., 12, 40114032, doi:10.5194/acp-12-4011-2012, 2012.

Petzold, A.: ICAROHS - Inter-Comparison of Aerosol Retrievals and Observational Requirements for Multi-Wavelength HSRL Systems, Final Report, 22169/NL/CT-STSE-ICAROHS TN1, 102 pp., ESA, 2011.

Petzold, A., Fiebig, M., Flentje, H., Keil, A., Leiterer, U., Schröder, F., Stifter, A., Wendisch, M., and Wendling, P.: Vertical variability of aerosol properties observed at a continental site during the Lindenberg Aerosol Characterization Experiment (LACE 98), J. Geophys. Res., 107, 8128, doi:10.1029/2001JD001043, 2002.

Petzold, A., Weinzierl, B., Huntrieser, H., Stohl, A., Real, E., Cozic, J., Fiebig, M., Hendricks, J., Lauer, A., Law, K., Roiger, A., Schlager, H., and Weingartner, E.: Perturbation of the European free troposphere aerosol by North American forest fire plumes during the ICARTT-ITOP experiment in summer 2004, Atmos. Chem. Phys., 7, 5105-5127, doi:10.5194/acp-7-51052007, 2007.

Petzold, A., Hasselbach, J., Lauer, P., Baumann, R., Franke, K., Gurk, C., Schlager, H., and Weingartner, E.: Experimental studies on particle emissions from cruising ship, their characteristic properties, transformation and atmospheric lifetime in the marine boundary layer, Atmos. Chem. Phys., 8, 2387-2403, doi:10.5194/acp-8-2387-2008, 2008.

Petzold, A., Rasp, K., Weinzierl, B., Esselborn, M., Hamburger, T., Dörnbrack, A., Kandler, K., Schütz, L., Knippertz, P., Fiebig, M., and Virkulla, A.: Saharan dust absorption and refractive index from aircraft-based observations during SAMUM 2006, Tellus, B61, 118-130, doi:10.1111/j.1600-0889.2008.00383.x, 2009.

Petzold, A., Veira, A., Mund, S., Esselborn, M., Kiemle, C., Weinzierl, B., Hamburger, T., Ehret, G., Lieke, K. and Kandler, K.: Mixing of mineral dust with urban pollution aerosol over Dakar (Senegal): impact on dust physico-chemical and radiative properties, Tellus, B63, 619-634, doi:10.1111/j.16000889.2011.00547.x, 2011.
Preißler, J., Wagner, F., Pereira, S. N., and Guerrero-Rascado, J. L.: Multi-instrumental observation of an exceptionally strong Saharan dust outbreak over Portugal, J. Geophys. Res., 116, D24204, doi:10.1029/2011JD016527, 2011.

Quinn, P. K., Anderson, T. L., Bates, T. S., Dlugi, R., Heintzenberg, J., von Hoyningen-Huene, W., Kulmala, M., Russel, P. B., and Swietlicki, E.: Closure in tropospheric aerosol-climate research: A review and future needs for addressing aerosol direct short-wave radiative forcing, Contrib. Atmos. Phys., 69, 547577, 1996.

Reitebuch, O., Lemmerz, C., Nagel, E., Paffrath, U., Durand, Y., Endemann, M., Fabre, F., and Chaloupy, M.: The airborne demonstrator for the direct-detection doppler wind lidar aladin on ADM-Aeolus. Part I: Instrument design and comparison to satellite instrument, J. Atmos. Ocean. Tech., 26, 2501-2515, 2009.

Sakai, T., Shibata, T., Kwon, S.-A., Kim, Y.-S., Tamura, K., and Iwasaka, Y.: Free tropospheric aerosol backscatter, depolarization ratio, and relative humidity measured with the Raman lidar at Nagoya in 1994-1997: contributions of aerosols from the asian continent and the pacific ocean, Atmos. Environ., 34, 431-442, doi:10.1016/S1352-2310(99)00328-3, 2000.

Sakai, T., Shibata, T., Iwasaka, Y., Nagai, T., Nakazato, M., Matsumura, T., Ichiki, A., Kim, Y.-S., Tamura, K., Troshkin, D., and Hamdi, S.: Case study of Raman lidar measurements of Asian dust events in 2000 and 2001 at Nagoya and Tsukuba, japan, Atmos. Environ., 36, 5479-5489, doi:10.1016/S13522310(02)00664-7, 2002.

Sakai, T., Nagai, T., Nakazato, M., Mano, Y., and Matsumura, T.: Ice Clouds and Asian Dust Studied with Lidar Measurements of Particle Extinction-to-Backscatter Ratio, Particle Depolarization, and Water-Vapor Mixing Ratio over Tsukuba, Appl. Opt., 42, 7103-7116, 2003.

Sakai, T., Nagai, T., Zaizen, Y., and Mano, Y.: Backscattering linear depolarization ratio measurements of mineral, sea salt, and ammonium sulfate particles simulated in a laboratory chamber, Appl. Opt., 49, 4441-4449, doi:10.1364/AO.49.004441, 2010.

Sasano, Y. and Browell, E. V.: Light scattering characteristics of various aerosol types derived from multiple wavelength lidar observations, Appl. Opt., 28, 1670-1679, doi:10.1364/AO.28.001670, 1989.

Sassen, K. and Hsueh, C.: Contrail properties derived from highresolution polarization lidar studies during SUCCESS, Geophys. Res. Lett., 25, 1165-1168, doi:10.1029/97GL03503, 1998.

Schuster, G. L., Vaughan, M., MacDonnell, D., Su, W., Winker, D., Dubovik, O., Lapyonok, T., and Trepte, C.: Comparison of CALIPSO aerosol optical depth retrievals to AERONET measurements, and climatology for the lidar ratio of dust, Atmos. Chem. Phys., 12, 7431-7452, doi:10.5194/acp-12-7431-2012, 2012.

Shimizu, H., Lee, S., and She, C.: High spectral resolution lidar system with atomic blocking filters for measuring atmospheric parameters, Appl. Opt., 22, 1373-1381, 1983, 1983.

Shipley, S., Tracy, D., Eloranta, E., Trauger, J., Sroga, J., Roesler, F., and Weinman, J.: High spectral resolution lidar to measure optical scattering properties of atmospheric aerosols. 1: Theory and instrumentation, Appl. Opt., 22, 3716-3724, 1983.

Stohl, A., Eckhardt, S., Forster, C., James, P., Spichtinger, N., and Seibert, P.: A replacement for simple back trajectory calculations in the interpretation of atmospheric trace substance mea- 
surements, Atmos. Environ., 36, 4635-4648, 2002.

Tesche, M., Ansmann, A., Müller, D., Althausen, D., Mattis, I., Heese, B., Freudenthaler, V., Wiegner, M., Esselborn, M., Pisani, G., and Knippertz, P.: Vertical profiling of saharan dust with Raman lidars and airborne HSRL in southern Morocco during SAMUM, Tellus, B61, 144-164, doi:10.1111/j.16000889.2008.00390.x, 2009a.

Tesche, M., Ansmann, A., Müller, D., Althausen, D., Engelmann, R., Freudenthaler, V., and Groß, S.: Vertically resolved separation of dust and smoke over Cape Verde using multiwavelength Raman and polarization lidars during Saharan Mineral Dust Experiment 2008, J. Geophys. Res., 114, D13202, doi:10.1029/2009JD011862, 2009b.

Tesche, M., Gross, S., Ansmann, A., Müller, D., Althausen, D., Freudenthaler, V., and Esselborn, M.: Profiling of Saharan dust and biomass-burning smoke with multiwavelength polarization Raman lidar at Cape Verde, Tellus, B63, 649-676, doi:10.1111/j.1600-0889.2011.00548.x, 2011.

Tsunematsu, N., Nagai, T., Murayama, T., Adachi, A., and Murayama, Y.: Volcanic Ash Transport from Mount Asama to the Tokyo Metropolitan Area Influenced by Large-Scale Local Wind Circulation, J. Appl. Meteor. Climatol., 47, 1248-1265, doi:10.1175/2007JAMC1644.1, 2008.

Wandinger, U., Müller, D., Böckmann, C., Althausen, D., Matthias, V., Bösenberg, J., Weiß, V., Fiebig, M., Wendisch, M., Stohl, A., and Ansmann A.: Optical and microphysical characterization of biomass-burning and industrial-pollution aerosols from multiwavelength lidar and aircraft measurements, J. Geophys. Res., 117, 8125, doi:10.1029/2000JD000202, 2002.

Wandinger, U., Tesche, M., Seifert, P., Ansmann, A., Müller, D., and Althausen, D.: Size matters: Influence of multiple scattering on CALIPSO light-extinction profiling in desert dust, Geophys. Res. Lett., 37, L10801, doi:10.1029/2010GL042815, 2010.

Weinzierl, B., Petzold, A., Esselborn, M., Wirth, M., Rasp, K., Kandler, K., Schütz, L., Köpke, P., and Fiebig, M.: Airborne measurements of dust layer properties, particle size distribution and mixing state of Saharan dust during SAMUM 2006, Tellus, B61, 96-117, doi:10.1111/j.1600-0889.2008.00392.x, 2009.

Weinzierl, B., Sauer, D., Esselborn, M., Petzold, A., Veira, A., Rose, M., Mund, S., Wirth, M., Ansmann, A., Tesche, M., Gross, S., and Freudenthaler, V.: Microphysical and optical properties of dust and tropical biomass burning aerosol layers in the Cape Verde region - an overview of the airborne in situ and lidar measurements during SAMUM-2. Tellus, B63, 589-618, doi:10.1111/j.1600-0889.2011.00566.x, 2011.
Weinzierl, B., Sauer, D., Minikin, A., Reitebuch, O., Dahlkötter, F., Mayer, B., Emde, C., Tegen, I., Gasteiger, J., Petzold, A., Veira, A., Kueppers, U., and Schumann, U.: On the visibility of airborne volcanic ash and mineral dust from the pilot's perspective in flight, J. Phys. Chem. Earth, 45-46, 87-102, doi:10.1016/j.pce.2012.04.003, 2012.

Wiegner, M., Gasteiger, J., Kandler, K., Werinzierl, B., Rastp, K., Esselborn, M., Freudenthaler, V., Heese, B., Toledano, C., Tesche, M., and Althausen, D.: Numerical simulations of optical properties of Saharan dust aerosols with emphasis on lidar applications, Tellus, B61, 180-194, doi: 10.1111/j.16000889.2008.00381.x, 2009.

Wiegner, M., Groß, S., Freudenthaler, V., Schnell, F., and Gasteiger, J.: The May/June 2008 Saharan dust event over Munich: Intensive aerosol parameters from lidar measurements, J. Geophys. Res., 116, D23213, doi:10.1029/2011JD016619, 2011.

Wiegner, M., Gasteiger, J., Groß, S., Schnell, F., Freudenthaler, V., and Forkel, R.: Characterization of the Eyjafjallajökull ashplume: Potential of lidar remote sensing, Phys. Chem. Earth, Parts A/B/C, 45-46, 79-86, doi:10.1016/j.pce.2011.01.006, 2012.

Winker, D. M., Hunt, W. H., and McGill, M. J.: Initial performance assessment of caliop, Geophys. Res. Lett., 34, L19803, doi:10.1029/2007GL030135, 2007.

Wirth, M., Fix, A., Mahnke, P., Schwarzer, H., Schrandt, F., and Ehret, G.: The airborne multi-wavelength water vapor differential absorption lidar WALES: system design and performance, Appl. Phys. B: Lasers and Optics, 96, 201-213, doi:10.1007/s00340-009-3365-7, 2009.

Xie, C., Nishizawa, T., Sugimoto, N., Matsui, I., and Wang, Z.: Characteristics of aerosol optical properties in pollution and Asian dust episodes over Beijing, China, Appl. Opt., 47, 49454951, 2008. 